\title{
A multidimensional adapted process model of teaching
}

\author{
Riitta-Leena Metsäpelto ${ }^{1}$ (D) Anna-Maija Poikkeus ${ }^{1} \cdot$ Mirva Heikkilä $^{2}$ • \\ Jukka Husu $^{2}$ • Anu Laine ${ }^{3}$ - Kristiina Lappalainen ${ }^{4} \cdot$ Marko Lähteenmäki $^{2}$ • \\ Mirjamaija Mikkilä-Erdmann ${ }^{2}$ - Anu Warinowski ${ }^{5}$ - in collaboration with • \\ Tuike liskala $^{2}$ • Sanna Hangelin ${ }^{2}$ • Sari Harmoinen ${ }^{6}$. \\ Anni Holmström ${ }^{2} \cdot$ Outi Kyrö-Ämmälä ${ }^{7}$. \\ Sami Lehesvuori ${ }^{1}$ - Ville Mankki ${ }^{8}$. Pirjo Suvilehto ${ }^{6}$
}

Received: 3 March 2020 / Accepted: 5 June 2021/Published online: 22 October 2021

(C) The Author(s) 2021

\begin{abstract}
In the present study, we aimed to specify the key competence domains perceived to be critical for the teaching profession and depict them as a comprehensive teacher competence model. An expert panel that included representatives from seven units providing university-based initial teacher education in Finland carried out this process. To produce an active construction of a shared understanding and an interpretation of the discourse in the field, the experts reviewed literature on teaching. The resulting teacher competence model, the multidimensional adapted process model of teaching (MAP), represents a collective conception of the relevant empirical literature and prevailing discourses on teaching. The MAP is based on Blömeke et al.'s, Zeitschrift für Psychologie, 223, 3-13, (2015) model which distinguishes among teacher competences (referring to effective performance of teachers' work), competencies (knowledge, skills, and other individual competencies underlying and enabling effective teaching), and situation-specific skills of perceiving, interpreting, and making decisions in situations involving teaching and learning. The implications of the MAP for teacher education and student selection for initial teacher education are discussed.
\end{abstract}

Keywords Teacher competences $\cdot$ Teacher competencies $\cdot$ Situation-specific skills $\cdot$ Initial teacher education $\cdot$ Student selection $\cdot$ Professional development

This study aimed to specify the key competence domains perceived to be critical for the teaching profession and to generate a teacher competence model that would depict the competences as a comprehensive whole. In the process of building the teacher

Riitta-Leena Metsäpelto

riitta-leena.metsapelto@jyu.fi

Extended author information available on the last page of the article 
competence model, we reviewed scientific literature on teaching as an expansive learning cycle (Engeström \& Sannino, 2010), involving actively constructing meaning and interpreting the discourse of the scientific community (Montuori, 2005). This process was carried out by an expert panel that included representatives from seven units providing university-based teacher education in Finland. The resulting teacher competence model is a collective interpretation of the current evidence base and the prevailing discourses on what teachers should know and be able to do.

The study was guided by the notion of teaching as an exceptionally complex and demanding profession requiring expertise that is developed, refined, and renewed through formal and informal learning throughout a teacher's education and career. This ongoing process entails transformations in the cognitive, motivational, and affective skills teachers use in the multiple tasks of teaching and adaptations of classroom practices (Desimone, 2009). This learning process has its starting point in initial teacher education (ITE), and the process continues during a professional's lifetime via continuing professional development (CPD). ITE and CPD focus on the teaching skills and bases of knowledge that make a difference in the classroom and contribute to improved student achievement (Hattie, 2009). Another goal is to help teachers construct strong professional identities and provide them a broad understanding of fundamental issues and values relevant for the profession in the larger societal context (e.g., comprehension of teachers' societal function). In the top-performing educational systems, the use research knowledge as the basis for teacher education indicates the professionalization of teaching (Toom et al., 2010). The burgeoning of educational literature, however, may blur the vision of what kind of skills and knowledge are needed in the teaching profession. Therefore, a conceptually coherent framework for teacher competences that aligns with contemporary knowledge about the science of teaching and learning and considers the complexity of teaching as knowledge and practice is called for (Grossman \& McDonald, 2008).

Current views characterize teacher professional development as a dynamic interplay of competences acquired in teacher education (and later in working life as part of work experience and CPD) and generic competencies that prospective teachers have when they enter teacher education programs (Klassen \& Kim, 2017). Although scholars have presented different approaches and definitions regarding teachers and teaching competence (Baumert \& Kunter, 2013; Blömeke et al., 2015; Koeppen et al., 2008), there is broad agreement that the construct of competence refers to teachers' ability to perform successfully and efficiently in teachers' work, while competency refers to a combination of knowledge, skills, traits, self-images, motives, values, and personal characteristics that enables and empowers teachers to act professionally and effectively in situations involving teaching and learning (Blömeke et al., 2015; Koster \& Dengerink, 2008).

Many - although not all - educational systems subject ITE candidates to selection procedures that evaluate the candidates' suitability for the teaching profession and potential for professional development (Hobson et al., 2010). Recently, interest in teacher education selection has increased (Bowles et al., 2014; Klassen \& Kim, 2019), and more reliable and valid selection methods have been developed in a concerted effort to improve the procedures (Bardach et al., 2021; Metsäpelto et al., in press). Selection procedures do not, however, always contain a clear framework for choosing targets for evaluation. The failure to explicate a conceptual framework of 
competencies predicting success in teaching is likely to hamper the validity of student selection processes.

Instead of constructing teacher competences narrowly through a limited set of skills, a comprehensive model outlining a teacher's successful performance at work (competences) and critical knowledge and skills enabling and facilitating it (competencies) would be an important step in gaining a more holistic understanding of key competences of teachers' work and their development at different career stages as a continuum from the entry phase through ITE to working life. To address this need, we used a process of creative inquiry (Montuori, 2005) and an expansive learning cycle (Engeström \& Sannino, 2010) to examine key competence domains perceived as critical for the teaching profession and to propose a comprehensive teacher competence model.

\section{Method}

\subsection{Participants and procedure}

Key competence domains were identified, and the teacher competence model was constructed, as part of the [Student Selection to Teacher Education in Finland Anticipatory Work for Future] project, a national initiative to improve and unify the student selection processes for ITE in Finland. A group of nine scholars and teacher educators (i.e., the authors of the present article) made up a panel of experts who met at regular intervals over an extended period to review relevant research literature on key concepts and models of teaching to come up through a collaborative dialogue with a holistic model. The expert panel created a preliminary model, which was further revised by the project's steering group in nine online meetings with representatives from the seven teacher education institutions (i.e., a total of 29 researchers and teacher educators). The iterative process of revisiting the key competence domains continued for 16 months, and the model was modified in several phases (see Appendix 1 Table 2). The discussions of the meetings were documented in detail, and events were organized at each institution to invite comments and views from a wider circle of researchers and teacher educators. The preliminary model was also presented to stakeholders, including representatives from the Ministry of Education and Culture and the Trade Union of Education in Finland, in professional meetings and conferences.

\subsection{Phases of model construction}

The model building contained features of an expansive learning cycle, through which the participants constructed a wider and more complex understanding of teaching competences by transforming their current knowledge into expanded knowledge structures in a multiorganizational setting through a multivoiced dialogue (Engeström \& Sannino, 2010). This endeavor was conceptually complex, inherently open to interpretation, personal sense-making, differing views, and contradictions. The differing views became the driving forces of the expansive learning cycle, requiring collective agency to break away from the existing understanding and leading to reflection, refinement, and, finally, consolidation of the key domains and the model (Engeström \& Sannino, 
2010). The model building included the following phases: (a) specifying the goal, searching for information, and brainstorming; (b) selecting Blömeke et al.'s (2015) model Selecting Blömeke et al.'s (2015) model as the starting point for constructing the model; and (c) establishing the research base and refining and finalizing the model.

\subsection{Specifying the goal, searching for information, and brainstorming}

The goal was to identify competence domains relevant across a wide range of teacher education programs, although we acknowledge that some specific teacher competences may take somewhat different forms or emphases across teacher professions, for instance, due to different content areas or age groups of learners and their needs (e.g., primary and secondary teachers). We reviewed previous research to identify models providing insight into competences of teachers with special content area expertise (e.g., mathematics teachers; Baumert \& Kunter, 2013), as well as literature presenting models of teacher effectiveness (Klassen \& Kim, 2019; Scheerens \& Blömeke, 2016), holistic models of good teachers (Korthagen, 2004), models of teacher knowledge (Shulman, 1987), and models depicting cross-cultural differences in competences (Klassen et al., 2018). These models served a specific predefined purpose, but their usefulness in describing a teacher's extensive and wide-ranging set of competences holistically was limited.

\subsection{Selecting Blömeke et al.'s (2015) model as the starting point for constructing the model}

We acknowledged a need for an approach that differentiates between teachers' overt and observable behaviors as they engage in teaching and other professional responsibilities (i.e., competences), and the underlying mental resources (i.e., competencies, such as knowledge, cognitive skills, and beliefs) that "represent the potential a teacher brings to the classroom" (Blömeke et al., 2020, p. 331). The latter are critical for performance, but more difficult to discern from the outside. Moreover, they form the prerequisites for successful action and lie behind competent observable behaviors (Weinert, 2001). The distinction between underlying (yet developing) competencies and teaching competences (proximal to practice itself) aligns with generic accounts that differentiate between possessing underlying attributes to perform competently (having competency) and the ability to accomplish the essential demands of the job (being competent; Burgoyne, 1989).

The two approaches of competency and competence are present in Blömeke et al.'s (2015) model, which depicts teacher competences as a continuum where dispositions (e.g., teacher knowledge) are dynamically interlinked with observable job performance (e.g., quality of instruction; see Fig. 1). Specifically, Blömeke et al. used the term dispositions to refer to cognitive and affective-motivational latent factors that underpin an individual's professional performance and are stable teaching resources. Observable teaching performance, however, includes successful accomplishment of professional tasks in real-life situations. Dispositions are transformed into teaching performance as mediated by situation-specific skills. They refer to a set of perceptual, interpretive, and decision-making processes taking place in the constant flow of classroom interaction (Blömeke et al., 2020; Blömeke \& Kaiser, 2017). 


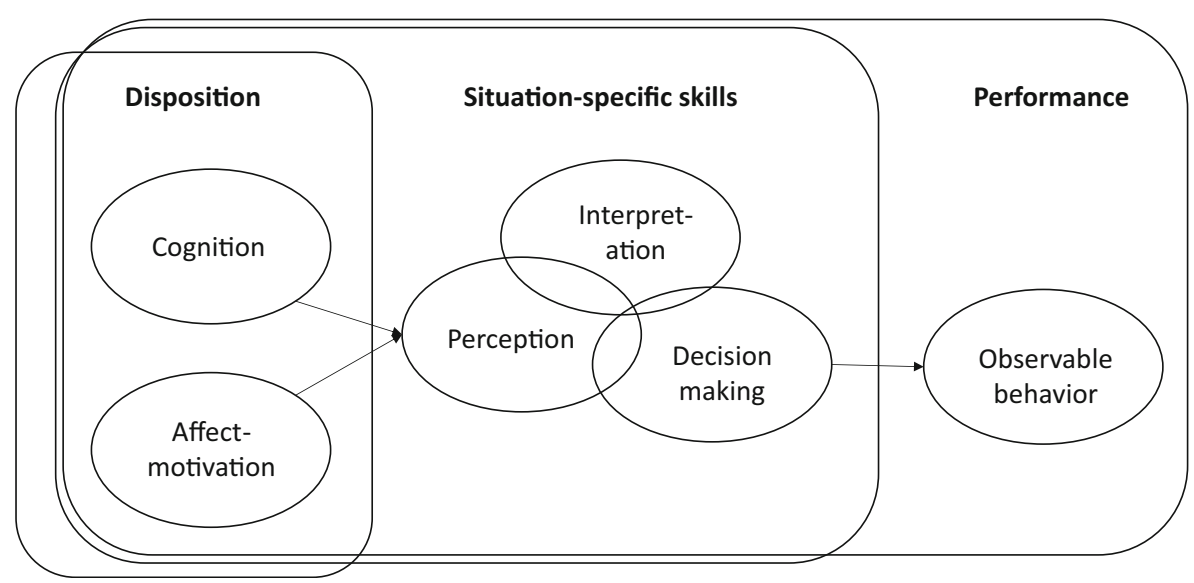

Fig. 1 A model of competence as a continuum (Blömeke et al., 2015)

Blömeke et al.'s (2015) model has gained prominence in the literature because it provides a comprehensive representation of the different types of resources necessary to master teaching (e.g., ZDM Mathematics Education, Special Issue, April 2016). Although the model as a whole has not been tested empirically, researchers have operationalized some of the general-level competencies as specific knowledge and measurable skills to accumulate understanding of their interrelationships. For instance, teachers' mathematical content knowledge has been found to be associated with their in-the-moment skills to notice students' thinking during math instruction (Bruckmaier et al., 2016; Kersting, 2008), which, in turn, has been found to predict teaching quality in the classroom and student outcomes (Kersting et al., 2012). A subgroup analysis by Blömeke et al. (2020) showed that lower secondary-grade mathematics teachers' knowledge of mathematics (e.g., content knowledge) and situation-specific skills of perceiving their students' math learning (e.g., diagnosing errors) and classroom events requiring management were associated with teachers' instructional quality within the different subgroups in a meaningful way. For instance, having high levels of knowledge and skills was linked with high levels of student support and high-quality math instruction. This finding suggests that the competences outlined in Blömeke et al.'s model can be translated into empirical measures, opening up avenues for empirical study of the model. In the present study, we used the Blömeke et al. (2015) model of teacher competences as a starting point and as an initial conceptual framework for developing our model.

\subsection{Establishing the research base and refining and finalizing the model}

Constructing the present multidimensional model included refining and specifying the competences of the Blömeke et al.'s (2015) model. During this process, the panel of experts conducted a focused overview of relevant research (Grant \& Booth, 2009). Dialogue among the experts was essential for generating individual and group reflection and translating the extensive and fragmented literature into a consensus model that would represent the broad context of the teaching profession 
(different programs ranging from early to special education and content disciplines). The panel of experts repeatedly explored the research base and refined the model until there was no further need to add new constructs. The final model was named the multidimensional adapted process model of teaching (MAP).

\subsection{Cultural embeddedness versus universality of teacher competences}

Teacher competences are acknowledged to be affected by the cultural, social, and taskspecific context in which the teaching takes place (Berliner, 2001). Klassen et al., 2018 have shown that some of the desirable teacher attributes are universal, while other attributes are specific to the educational environment and policy culture. The teacher competence model presented in this study is embedded in the context of teacher education and the teaching profession in Finland, which has distinct features. Finnish teachers typically exercise a high degree of pedagogical autonomy, and they are viewed as trusted professionals with a research-based teacher education that qualifies them to implement and develop curricula and utilize assessment practices with a great degree of independence (Sahlberg, 2010). Generally, what is considered competent teaching in a particular context (e.g., among learners of different ages, in schools located in different areas, across different educational systems) depends in part on the specific demands of the work and its locally constructed meanings (Stoof et al., 2002).

Although these contextual dependencies must be acknowledged, the discourses about teachers and teaching are increasingly constructed jointly in the globalized community of scientists, educators, and policymakers via dialogue facilitated by communication technologies and transnational policy processes (e.g., the Bologna Process). Shared construction and interpretation of high-quality or effective teaching are also enabled by the growth of international comparative studies; as a result, our understanding of high-quality teaching has become more unified globally (Paine et al., 2016). Scientific educational literature commonly defines high-quality teaching as learner-centered and constructivist with an emphasis on students' active learning and problem-solving and teacher's learning support for a diverse student body. Thus, teaching quality is constructed in an increasingly unitary fashion beyond local community or nation-state norms and traditions (Paine et al., 2016; Schleicher, 2011). The global trend in teacher research includes an expansion of knowledge about teaching in an increasingly open and collaborative international research community advancing further synthesis of views and frameworks. Against this backdrop, the goal of this study was to build a model focused on generic and transferable teacher competencies that would transcend the immediate proximal environmental and situational variations in which teaching and learning may occur, while acknowledging that the contextual underpinnings of the teaching profession are always situated in a specific educational and cultural setting.

Multidimensional adapted process model of teaching The MAP is depicted in Fig. 2. Blömeke et al.'s (2015) competence model served as the main starting point, and we developed the model further in several ways. These modifications of and novel contributions to the competence model are described in detail. 


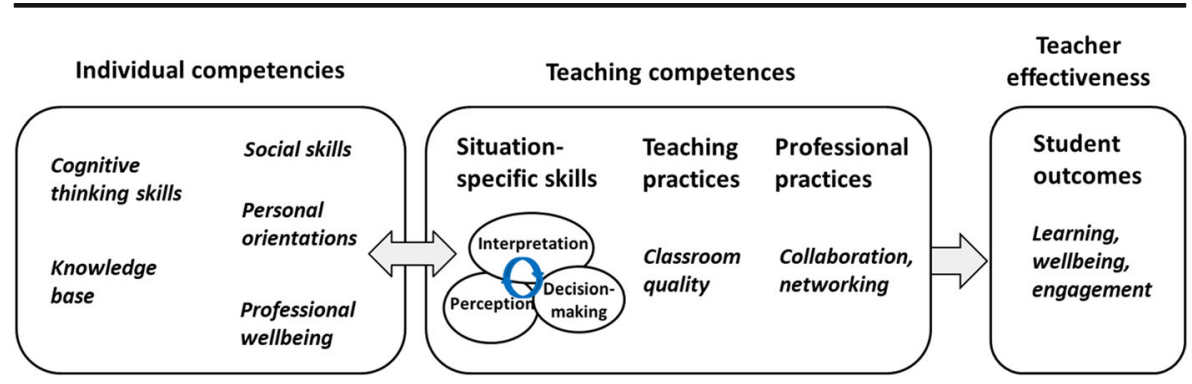

Fig. 2 Multidimensional adapted process model of teaching (MAP)

\subsection{Teacher effectiveness at the student level}

In the MAP, we use the term "teacher effectiveness" to refer to the contribution of teaching to student outcomes, for instance, to student gains in basic academic skills and learning objectives as well as motivational, social, and affective outcomes and student engagement in learning (Seidel \& Shavelson, 2007). Indicators of teacher effectiveness may include summative or formative assessments or standardized tests but also students' evaluations of teaching that capture their experiences and perceptions of the classroom and the teacher (Goe et al., 2008). We use the term "process model" to convey the view that teachers' competences contribute to learning and growth at the student (and student group) level. Students, however, are not seen only as recipients of instruction but also as active agents who influence the learning process and whose characteristics, initiatives, and active efforts evoke a range of instructional patterns and responses among the teachers (Nurmi \& Kiuru, 2015).

\subsection{Teaching practices and professional practices as indicators of teaching competences}

In the MAP, teaching practices, defined through the quality of classroom processes, are viewed as among the key indicators of teaching competences. Classroom quality (Hamre et al., 2013) is affected by the teacher's ability to organize optimal learning environments to maximize students' engagement and knowledge-building and to facilitate a community of learners. Skilled teachers emphasize support for students' active engagement, adapt their instruction based on student initiatives, and value students' thinking (Ball et al., 2009). Classroom interventions promoting dialogic teaching have been shown to foster productive classroom talk (Mercer, 1996) and negotiation of ideas and views (Alexander, 2006), while child-centered teaching practices (i.e., teacher sensitivity to children's interests) positively predict academic outcomes (Lerkkanen et al., 2016; Perry et al., 2007). In addition, instructional approaches that facilitate knowledge to be readily received, organized, stored, and retrieved by learners (Ertmer \& Newby, 2013) and that reinforce positive and decrease disruptive behaviors (Karhu et al., 2019) have been found to be effective in responding to students' needs and in advancing their learning.

High-quality teacher-student interaction in the classroom is depicted in three main domains in Hamre et al.'s (2013); see also Praetorius et al., 2018) teaching through 
interactions (TTI) framework. Emotional support refers to teachers' skills in creating and maintaining a positive emotional atmosphere in the classroom and responding sensitively to students' needs. Classroom organization refers to setting clear behavioral expectations and effective routines and implementing proactive classroom behavior management, and instructional support refers to promoting students' higher-order thinking and providing feedback that expands understanding. Comprehensive research evidence links high-quality teaching practices to student outcomes across various age groups (Pianta et al., 2012) and with respect to various outcomes, most strongly academic achievement (Allen et al., 2011; Baumert et al., 2010; Hamre \& Pianta, 2005).

In MAP, in addition to teaching practices displayed and enacted in the classrooms, teacher competences include professional practices. Effective teachers are skilled at planning and preparing instruction by organizing the learning content into lessons that support students to accomplish the learning objectives (Danielson, 1996, 2013), and utilizing analytical insight in selecting learning goals, optimal forms of assessment, materials, and resources. Other professional competences include communicating with parents and engaging them in partnership with the school, actively participating in the professional community (Danielson, 1996, 2013; Stoll et al., 2006), and advancing one's professional development (Danielson, 1996, 2013), for instance, by having a motivational state to incorporate new understanding in practice (Maurer, 2002). Professional competences also include engagement in mentoring and leadership roles and pedagogical development in one's school community (Danielson, 1996, 2013; Harris, 2009; Kilinç, 2014).

\subsection{Situation-specific skills as markers of teaching competences}

In line with Blömeke et al.'s (2015) competence model, the MAP emphasizes situationspecific skills, which teachers utilize while navigating moment-to-moment situations in the classroom and the school (Seidel \& Stürmer, 2014; Sherin et al., 2011; van Es \& Sherin, 2002). These competencies include the intertwined, cyclical processes of perception, interpretation, and decision-making(the PID model; Blömeke et al., 2015; Kaiser et al., 2015). The PID model consists of gleaning perceptions of significant events in an instructional setting, interpreting their meaning, and making decisions, such as choosing an instructional approach (Kaiser et al., 2015). The related constructs of professional vision and teacher noticing refer to a teacher's ability to detect student thinking and classroom events that are relevant for learning and to use professional knowledge to interpret them (van Es, 2011; van Es \& Sherin, 2002).

Perceiving student thinking and other relevant information in complex classroom environments has been found to characterize expert teachers. According to Miller (2011), skilled viewing means that while enacting a lesson, teachers (a) can focus on student understanding; (b) systematically scan most or all students (while novices are likely to focus on some students and ignore others); and (c) effectively identify situations that require immediate intervention (e.g., student misunderstandings or misbehavior). Expert teachers have been shown to process visual information faster, distribute their visual attention more evenly, monitor more of the classroom than novices (van den Bogert et al., 2014), and perceive meaningful events more quickly and accurately than novices (Berliner, 2001). 
When interpreting events in an instructional setting, teachers rely on their knowledge of teaching and learning and integrate their perceptions of real-time events with their previous knowledge of students, classroom events, and contextual factors (Seidel \& Stürmer, 2014; van Es \& Sherin, 2002). This knowledge-based reasoning or interpretation (Blömeke, 2017; Kaiser et al., 2015) entails abilities to describe an event, evaluate its quality, and make predictions about it in terms of student thinking and learning. Decision-making refers to the teacher responding to classroom events and adjusting his or her interaction. When making instructional decisions, teachers integrate various types of information about the students, the subject, and the setting (Shavelson \& Stern, 1981). However, contextual conditions, such as school community norms, also shape a teacher's decision-making by influencing what is seen as preferable or acceptable courses of professional action (Lande \& Mesa, 2016).

Teachers' skills of perceiving and making sense of students' ideas and thinking are necessarily interwoven with teachers' skills of attending to and regulating motivational, social, and emotional aspects of classroom interaction. Events in the classroom trigger a range of emotions in teachers and students alike (Hargreaves, 1998), and invite diverse affects, from enthusiasm to disinterest or defiance (Rosiek \& Beghetto, 2009). Differences have been documented between expert and novice teachers, for instance, in noticing disengaged and off-task students (Wolff et al., 2017), indicating that teacher noticing has content-specific (perceiving student thinking in a specific subject) and generic components (e.g., perceiving classroom management; Steffensky et al., 2015).

Recently, research on situation-specific skills has increased with systematic reviews especially in the fields of mathematics and science, for example, on conceptualizations of teacher noticing and knowledge-based reasoning (Chan et al., 2021), theoretical and methodological frameworks and differences between experts and novices (Stahnke et al., 2016), and methodological processes of research focused on teacher noticing (Amador et al., 2021). This evidence suggests that situation-specific skills are an integral part of teachers' work that should be supported in teacher education. However, only scant empirical evidence is available that shows direct links between teachers' skills in perceiving and interpreting students' learning and thinking, and effective instruction and student learning outcomes (Kersting et al., 2012), which points out a clear need for further research.

\subsection{Individual competencies}

In the MAP, teacher competencies are understood as underlying resources, skills, or knowledge that is related to and explains effective performance (Table 1). Contrary to paradigms that define competencies narrowly, such as only cognitive competencies (Koeppen et al., 2008), we follow the approach adopted in the Blömeke et al. model, acknowledging that competencies can range from generic competencies (e.g., information-processing abilities) to affective and motivational competences (e.g., abilities to regulate emotions) and to domain-specific competences (e.g., content knowledge on specific subject) (Blömeke \& Kaiser, 2017). Cognitive competencies refer to general cognitive resources and knowledge that are known to contribute to successful teaching (Guerriero, 2017; Sternberg \& Horvath, 1995). In the MAP, cognitive competencies encompass the knowledge base and cognitive thinking skills. During the last decade, researchers have increasingly acknowledged the importance of nonacademic or 
noncognitive competencies for success in working life (Heckman \& Kautz, 2012) and in the teaching profession (Madni et al., 2015). The skills and attributes subsumed under the rubric of noncognitive competencies include a broad range of characteristics, such as social and communication skills and motivational orientations. The concept of noncognitive competencies, however, is imprecise in that it appears to imply that some competencies would be devoid of cognition, while, in fact, cognitive processes influence almost all aspects of individuality. Notwithstanding this pertinent critique, the cognitive/noncognitive dichotomy is recognized and widely used in the research field (Klassen et al., 2018). The characterizations of noncognitive qualities or skills, however, vary in specificity and breadth, and there is no universally shared classification or taxonomy for their categorization. We include in the MAP three distinct, broad domains of noncognitive competencies. The first domain, social skills, focuses on how a teacher manages relations with others. The second domain, personal orientations, involves the management of oneself in the role of teacher. The third domain, professional well-being, concentrates on how a teacher manages his or her work. These competencies domains in the MAP are described in the following.

Knowledge base Teachers bring a broad range of cognitive resources to teaching situations, for instance, different aspects of knowledge and ways of thinking and communicating. Shulman's (1987) seminal work provides the best-known framework

Table 1 Individual competencies in the MAP

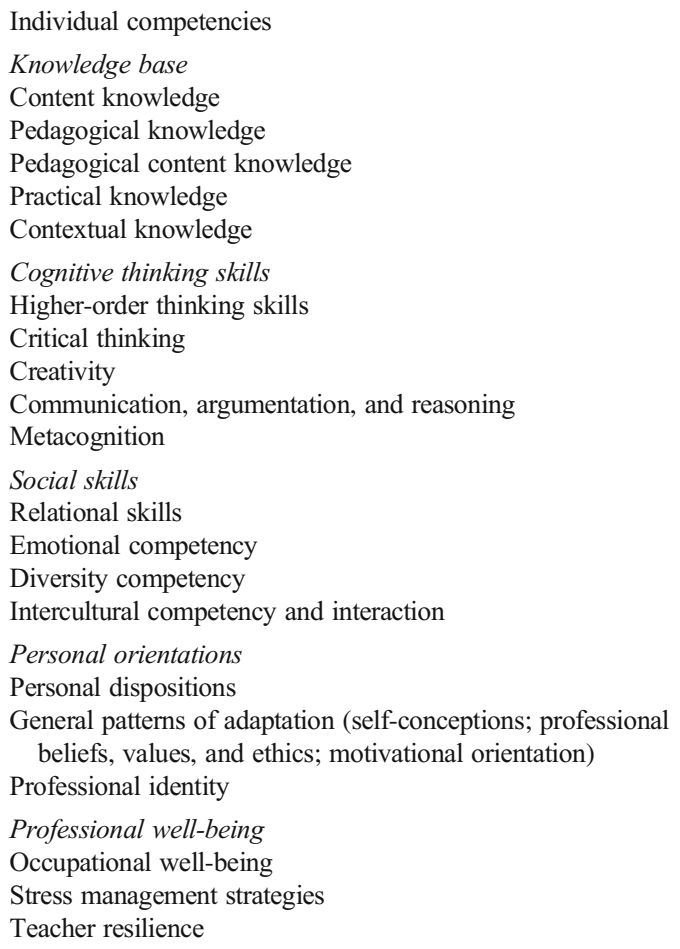


of knowledge categories that are important in the teaching profession. In the MAP, the knowledge base includes five types of knowledge: content knowledge (CK), pedagogical knowledge $(\mathrm{PK})$, and pedagogical content knowledge (PCK) form the prime knowledge base for teaching (Gess-Newsome, 1999). The knowledge base also includes practical and contextual knowledge (Shulman, 1987).

Content knowledge refers to domain-specific knowledge of facts, concepts, and key phenomena, comprehension of the structure of the subject knowledge and how such knowledge is generated (Shulman, 1987; see also Ball et al., 2008), and a thorough understanding of the curricular content to be taught (Baumert et al., 2010). The literature suggests a strong connection between teachers' $\mathrm{CK}$ and student learning (Gess-Newsome et al., 2017; Sadler et al., 2013; Ward et al., 2015). Pedagogical knowledge refers to knowledge of the principles of classroom management (Shulman, 1987), instruction, and assessment, as well as an understanding of the cognitive, emotional, and motivational factors that regulate learning, and how these factors develop in students (Guerriero \& Révai, 2017; Voss et al., 2011). There is evidence for links between PK and teaching quality (Gess-Newsome et al., 2017), for example, with respect to teachers' ability to recognize and interpret instructionally significant events in the classroom (König et al., 2014), to provide high-quality instruction (Voss et al., 2011), and to use effective classroom management strategies (König \& Kramer, 2016).

Pedagogical content knowledge, in turn, combines the content of the subject and its teaching (Shulman, 1987). This domain includes knowledge of effective methods for teaching the subject, employing differentiation that adapts to students' ability levels, and being knowledgeable of typical ways the topic can be (mis)understood(van Driel et al., 1998). PCK is considered a fundamental knowledge domain unique to the teaching profession because it refers to how teachers transform their understanding of the subject matter into classroom instruction (Shulman, 1987). At the core of PCK is knowledge of students and their learning (e.g., acquisition of a particular academic skill and the challenges it presents), and knowledge of instructional strategies and representations, both of which are grounded in subject-matter knowledge, teaching experience, and ensuing reflection (van Driel et al., 1998). The literature documents the relevance of PCK knowledge for fostering student achievement (Baumert et al., 2010; Hill et al., 2005). In an extension of Shulman's formulation of the PCK model, Mishra and Koehler (2006) added integration of digital technology into pedagogy (technological pedagogical content knowledge [TPACK]) as a crucial teacher competency. It is also notable that there is a link between content knowledge and pedagogical content knowledge, as a teacher's enacted PCK can be transformed from immature to mature as a function of accumulating CK (Ward et al., 2015).

Practical knowledge refers to knowledge of teaching that is embedded in the artistry of practice, situated and constructed in everyday life in schools and classrooms, built on knowledge from previous practices, and acquired through deliberative reflection about these practices (Cochran-Smith \& Lytle, 1999). Practical knowledge, or what Shulman (1987) called "wisdom of practice", is not formal knowledge, but it emerges in response to immediacy of classroom life, for instance, as a process of acting and thinking wisely, choosing among alternatives, and focusing on certain particularities of classroom (Cochran-Smith \& Lytle, 1999). Aspects of practical knowledge are often tacit, as they are implicit in the patterns of action and difficult for teachers to articulate 
(Schön, 1995). According to Bennet and Bennet (2008), tacit knowledge can take the form of intuitive or embodied knowledge expressed in bodily, kinesthetic, or sensory form. For instance, know-how of a skilled music teacher's tacit knowledge may include differentiation of tones or pitches of the musical instrument. The use of this knowledge accompanied by teachers' explanations (Shulman, 1987) supports students to acquire such knowledge.

Finally, in line with Shulman's (1987) framework, skilled teachers also have welldeveloped contextual knowledge, that is, understanding of the sociocultural context in which the teaching occurs. Schools are intricate and complex settings embedded in local communities and are affected by the norms and values of the broader social and societal structures. This knowledge includes understanding of and critical reflection on how social policies and political, cultural, and economic factors shape learning, teaching, and schooling and influence the equitability of education (Darling-Hammond, 2006). In addition, teachers should possess knowledge of educational history (Toom et al., 2010).

Cognitive thinking skills Cognitive skills or abilities, referring to a broad category of mental processes ranging from general intelligence and related basic skills (e.g., verbal and numerical processing, attentional, and memory skills) to higher-order thinking skills (e.g., skills for analyzing, evaluating, creating, and applying knowledge; Krathwohl, 2002), appear to be differentially relevant to the work of a teacher. General intelligence, assessed using IQ tests, appears not to contribute to teacher effectiveness (Bardach \& Klassen, 2020). However, a recent study with a large international data set showed a relation between teacher's numerical and verbal abilities and student performance (Hanushek et al., 2019). The MAP narrows the scope of critical cognitive abilities specifically to higher-order thinking skills, referring to abilities "to reason, plan, solve problems, think abstractly, comprehend complex ideas, learn quickly and learn from experience" (Gottfredson, 1997, cited in Bardach \& Klassen, 2020). These skills are considered important due to the complex nature of teachers' work, which requires them to monitor student understanding and retrieve, search, assemble, and translate information (Winne, 2001). These skills are also required in university-based academic teacher education, where completion of thesis studies (e.g., in Finland, a master's thesis) is required as part of education leading to a degree.

A useful framework for specifying the higher-order thinking skills relevant for teachers and teacher education (Häkkinen et al., 2017; Valtonen et al., 2021) is provided by the generic skills described in twenty-first-century skills (Binkley et al., 2012). One of the four relevant elements (see Binkley et al., 2012) is critical thinking, which refers to purposeful and goal-directed activity in which one examines ideas, analyzes arguments, uses different modes of reasoning (e.g., inductive, deductive), and synthesizes information to formulate beliefs and solve problems. Creativity involves generating original or inventive ideas and the willingness to analyze, evaluate, and refine one's own ideas by being open and responsive to other people's new ideas. Effective communication refers to an ability to articulate thoughts and ideas and to formulate arguments in a convincing manner using diverse communication skills and media. Finally, metacognition refers to the knowledge of one's own cognition and the regulation of cognitive processes, along with an ability to plan, monitor, and evaluate learning processes. 
In the MAP, higher-order thinking skills are considered crucial for teachers' work. Critical thinking skills are needed in effective problem-solving and decision-making, development of sound reasoning, and adoption of an intellectually productive stance (Dwyer et al., 2014). Creativity translates into teachers' skills in responding to teaching situations in novel and innovative ways (Sternberg \& Horvath, 1995), offering students meaningful and activating learning experiences, and responding to their initiatives (Dobbins, 2009). A teacher's ability to clearly communicate lesson goals and the aims of learning tasks leads to more meaningful student learning by activating knowledge structures and integrating new information. Clear communication has been shown to have a moderate-to-large effect on students' affective and cognitive learning (Hattie, 2009; Titsworth et al., 2015). In addition, teaching requires engagement in complex metacognitive regulation while simultaneously monitoring students' understanding and thinking and using this insight to improve instruction (Duffy et al., 2009). Learners' responsibility for their own learning is increasingly highlighted at all levels of education, which requires supporting teachers' metacognition (Kallio et al., 2020).

Social skills Teachers consider social skills the most important skill set required in daily classroom work (Tynjälä et al., 2006; see also Jennings \& Greenberg, 2009) and critical for collegial collaboration (Tynjälä et al., 2016). According to Denham (2005); Denham et al., 2003), ways of relating to other people are determined by relational and emotional competency skills, which reveal individual differences at the preschool age. Individuals with strong relational skills know when and how to listen, take turns, seek help, and show empathy. These individuals are skilled in managing conflict and negotiating differing viewpoints through cooperation and teamwork (Denham, 2005; Jennings \& Greenberg, 2009). Using interview data from sixth to 12th graders, Cothran et al. (2003) showed that caring teachers who communicate with and listen to their students, and treat them with respect, were perceived by students as effective class managers. Supportive relationships between a teacher and students are critical for students to feel safe to seek help and take academic risks (Newman, 2000).

Effective functioning in relationships also entails skills in managing emotions. Denham et al. (2009, p. 42) defined emotional competence as the "multifaceted ability to be aware of one's own and others' emotions and to act on this awareness, to negotiate interpersonal exchanges and regulate emotional experiences." Teachers' emotions influence teacher and student behavior, motivation and cognition, and teacher-student relationships (Keller et al., 2014; Sutton \& Wheatley, 2003). Emotionally competent teachers recognize their own emotions, understand how they are triggered, and are skilled in empathically attuning to the emotions of students and other people. Emotional competence also encompasses regulating negative affect and inhibiting inappropriate behaviors (Denham, 2005). Jennings and Greenberg (2009) used the concept of social-emotional competencies to refer to a teacher's ability to recognize students' emotions, to understand the cognitive appraisals that may be associated with these emotions, and to discern how these cognitions and emotions (de)motivate students' behavior. Although the significance of teachers' relational skills and emotional competence is acknowledged in teacher research (Jennings \& Greenberg, 2009), the field is under researched, and more research is needed especially in relation to student outcomes (Tynjälä et al., 2016). 
Teachers' social skills include acknowledging and responding to diversity (e.g., with respect to a range of student characteristics and mental and physical abilities). Diversity competence refers to sensitivity and attitudes that prevent and preclude differential treatment and marginalization processes in the classroom community (Booth \& Ainscow, 2011; Spratt \& Florian, 2015) and promote responding to individual differences in learning in ways that support and respect the dignity of each child. In turn, intercultural competence and interaction refer to an awareness of the cultural context and an ability to navigate and communicate sensitively across multicultural contexts of ethnicity, language, religion, age, gender, sexuality, and social class (Bennett, 2009). Intercultural competency builds on attitudes, knowledge (e.g., cultural self-awareness and knowledge), adaptability, and ethno-relative views, and it is manifested in behavior and communication appropriate in diverse intercultural situations (Deardorff, 2006). In the school community, teachers can increase intercultural knowledge by proactively working against misunderstandings or prejudices and by fostering mutual enrichment among culturally diverse students (Le Roux, 2002). These competencies are increasingly important in today's multicultural schools, which use inclusive education as a core organizing principle.

Personal orientations In the MAP, we use the concept of personal orientations to refer to the continually evolving process with which a person determines and manages aspects of self, personal and motivational characteristics, and one's identity as a teacher. The approach draws from personality psychology and aligns with views presented by McAdams and Pals (2006) in which personal orientations are divided into three domains. The first domain concerns a teacher's habitual patterns of behaviors, thoughts, and emotions (or personal disposition). The second domain describes the general patterns of adaptation to the teacher profession that individuals exhibit in response to varying situations, contexts, and roles at work, including selfconceptions; professional beliefs, values, and professional ethics; and motivation. Finally, the third domain concerns a teacher's professional identity as an ongoing process of interpreting and reinterpreting work-related experiences. These three domains represent distinct facets of individual differences and universal dimensions of human behavior.

Personal dispositions Personal dispositions describe individual differences in thoughts, behaviors, and emotions that account for consistency in individual functioning across situations and over time (McAdams \& Pals, 2006). Effective teachers have been characterized, for instance, as helpful, friendly (Goh \& Fraser, 1998), and fair (Chory-Assad, 2002). One of the strongest predictors of job success across a wide range of occupations is the predisposition to be organized, hardworking, and committed (Heckman \& Kautz, 2012), which aligns with the Big Five personality trait of conscientiousness (Costa Jr \& McCrae, 1992). Conscientiousness among teachers is linked, for instance, with a higher sense of personal accomplishment as a teacher (Kokkinos, 2007). Klassen and Tze (2014) conducted a meta-analysis of the association between teacher personality traits and teacher effectiveness, which showed a modest but significant relationship. Another recent meta-analysis corroborated these findings showing that the Big Five domains of extraversion, conscientiousness, emotional stability, and 
openness are positively albeit modestly associated with teacher effectiveness, especially with student evaluations of teaching quality (Kim et al., 2019).

Teachers' dispositions also seem to have a significant influence especially on student perceptions of the learning climate in the classroom. Roloff et al., 2020; see also Kim et al., 2018) showed with longitudinal data collected over 10 years that agreeableness, measured before entry to teacher education, positively predicted student-rated ability of in-service teachers to create a supportive social environment in which students felt secure and personally valued. Together, these findings show moderate but consistent support for the notion that stable personal dispositions, such as personality traits, form an important context for student learning and academic progress. Personality traits, as relatively stable dimensions of individuality, are typically not key focuses of teacher education (Metsäpelto et al., in press), but they have been suggested to have potential value as targets of evaluation in the student selection phase (Kim et al., 2018; Roloff et al., 2020). Some education systems utilize personality trait measures in selecting students for teacher education programs (Bowles et al., 2014).

General patterns of adaptation to the teacher profession The second aspect of personal orientation, general patterns of adaptation, captures the varied ways in which an individual adjusts to different situations, contexts, and roles as a teacher during a particular period of the teacher's life span (e.g., novice versus experienced teacher). The MAP specifies three broad constructs that characterize an individual's adaptation to the teacher profession: (a)self-conceptions (e.g., teacher self-efficacy); (b) professional beliefs, values, and ethics; and (c) motives and interests related to the work as a teacher. These constructs represent patterns of behaviors and thoughts that are contextualized in time and situations and are relevant for the professional role of a teacher.

Self-conceptions refer to an individual's beliefs and perceptions about himself or herself (Baumeister, 1999). The concept of teacher self-efficacy has been a focus of much research, referring to "the teacher's belief in his or her capability to organize and execute courses of action required to successfully accomplish a specific teaching task in a particular context" (Tschannen-Moran et al., 1998, p. 233). Teacher self-efficacy beliefs center, for instance, on perceived efficacy for classroom management, instructional strategies, and student engagement (Tschannen-Moran \& Hoy, 2001). These beliefs draw heavily on mastery experiences (Morris et al., 2017; Tschannen-Moran et al., 1998), but they can also derive from the vicarious experience of observing others and from emotional and physiological experiences that teachers interpret as indicators of personal competence in teaching and learning situations. The importance of teacher self-efficacy is related to its wide-ranging implications for teachers' work and student learning (Zee \& Kooman, 2016). Higher self-efficacy beliefs have been found to have positive links with a range of students' academic outcomes, including literacy and math skills development (Guo et al., 2012; Zee \& Kooman, 2016), higher observed instructional and classroom quality (Klassen \& Tze, 2014; Zee \& Kooman, 2016), and various aspects of teachers' psychological well-being (e.g., sense of personal accomplishment, job satisfaction, and commitment to the teaching profession; (Kasalak \& Dagyar, 2020; Zee \& Kooman, 2016)).

Professional beliefs, values, and ethics are acknowledged to influence a teacher's practical decisions and strategies in the classroom. They include beliefs about the 
nature of knowledge in academic domains and the desired student competencies in these domains (Buehl \& Alexander, 2009; Richardson, 1996). These beliefs may emanate from previous experiences with schooling, or they may echo understandings that have been agreed upon within a school community (Richardson, 1996). In contrast to "knowledge," which can be seen to comprise verifiable thoughts and ideas, beliefs are subjective claims that a person accepts as true and which often resist change even when confronted with contradictory evidence (Buehl \& Alexander, 2009). One aim of teacher education is to invite student teachers to critically reflect on their beliefs about learning and schooling to progress from preconceived perspectives to research-based knowledge of teaching and learning (Graber, 1996). In addition to beliefs, teachers' personal values and their commitment to ethical standards and moral obligations of the profession guide their educational practice in classrooms and the school community. Professional values and ethics form one of the key characteristics of teacher professionalism (Campbell, 2008a), and they have a bearing on teachers' behaviors in morally laden situations, their ability to reason about and solve moral dilemmas, and their moral opinions, which, in turn, may influence students' moral growth and the moral ethos of the school (Campbell, 2008b; Husu \& Tirri, 2001).

Motivational orientation among teachers refers to motivation toward the profession composed of internal and external factors that drive teachers to be interested in and continually committed to their work (Richardson et al., 2014). A widely acknowledged motivational framework, the expectancy-value theory (Eccles, 2005), asserts that achievement-related choices, such as educational and vocational choices, are dependent on expectations of success and the value an individual attaches to a career choice. The value component of intrinsic value captures how much a person enjoys working as a teacher. The other values are the usefulness of choosing the teaching profession (utility value) and the importance of the career choice for the individual (attainment value). Candidates seeking to enter a teacher education program typically find the profession enjoyable (intrinsic value), believe they possess the desired abilities, and have positive previous teaching and learning experiences (Watt et al., 2012). The reasons for entering the teaching profession have been shown to predict subsequent professional engagement and teaching quality (Richardson \& Watt, 2014).

Professional identity Professional identity, the third aspect of personal orientation, refers to a dynamic process of interpreting and understanding oneself as a professional actor in a role negotiated during one's life course and influenced by aspirations to be the kind of professional one desires to be (Beijaard et al., 2004). A strong professional identity supports teachers' sense-making of their teaching, their profession, and their teaching practices (Akkerman \& Meijer, 2011). Identity is constructed and reconstructed by stories and narratives in dialogue with others, and it is affected by cultural values, norms, and structures (Beijaard et al., 2004). The development of a teacher's professional identity is linked with professional agency through the process of taking active initiatives, influencing one's work community, and having authority and ownership (Eteläpelto et al., 2013). A strong sense of agency empowers teachers to resist or change existing practices (Beauchamp \& Thomas, 2009). 
Professional well-being Major sources of teachers' job satisfaction include witnessing students make progress and developing one's professional skills and knowledge (Dinham \& Scott, 2000). Job satisfaction is one component of occupational well-being, which includes enthusiastic and energized engagement with work. Work engagement is defined as a work-related state of mind characterized by vigor, dedication, and absorption (Schaufeli et al., 2002), and it is positively and reciprocally associated with personal and job resources. Teachers who are able to draw upon job resources, such as supervisory support, and who perceive that they have an influence over their work, work in a positive social climate, and can express innovativeness have been shown to be more engaged in their work and to feel stronger organizational commitment (Hakanen et al., 2006). Moreover, high work engagement combined with an ability to maintain a healthy emotional distance from one's work predicts effective instructional performance among teachers (Klusmann et al., 2008).

The teaching profession is known, however, for having complex demands that may exert feelings of strain and stress (Kyriacou, 2001). Teacher stress refers to negative emotions resulting from some aspect of work, such as work overload, coping with change, and teaching students who lack motivation (Hakanen et al., 2006). Individuals are differently vulnerable to experiencing stress due to excessive job demands, and for some, difficulties in coping may lead to burnout, a state of emotional exhaustion, cynicism, and a lowered sense of personal accomplishment (Maslach et al., 2001). Teachers' stress management strategies include the use of palliative techniques aimed at lessening the feeling of stress (e.g., changing the appraisal of the situation) and actions to eliminate the sources of the stress (e.g., developing new skills to meet job demands; Kyriacou, 2001). In addition, a teacher's ability to use social resources in the school community promotes coping and prevents burnout (Pietarinen et al., 2013). Resilient teachers have the capacity to overcome personal vulnerabilities and environmental stressors and recover even in the face of adversity (Gu \& Day, 2007). Teacher resilience refers to a dynamic interplay between risk and protective factors that may include individual attributes and contextual features. The ways of responding to challenging or adverse situations are complex and idiosyncratic, and they involve dynamic processes of interaction over time between the individual and the environment (Beltman et al., 2011).

Recent meta-analyses (García-Arroyo et al., 2019; García-Carmona et al., 2019) indicated that teacher stress and burnout are relevant problems in many countries, exerting significant negative effects on the professional paths of individual teachers. Consistent evidence is also accumulating about negative implications at the student level (Madigan \& Kim, 2021). Evidence indicates, for instance, that teachers with high stress and low coping strategies are more likely have classrooms with high rates of student behavior problems and lower academic achievement (Herman et al., 2018). In parallel, teachers' emotional exhaustion has been found to have negative links with students' school grades, standardized achievement test scores, school satisfaction, and perceptions of teacher support (Arens \& Morin, 2016). Thus, ITE programs are increasingly encouraged to include pedagogical programs and course content to prevent or reduce the impact of teacher exhaustion (García-Carmona et al., 2019; Mansfield et al., 2016). 


\section{Discussion}

The MAP aims to specify and depict the key competence domains perceived to be critical for the teaching profession. In particular, the aim was to generate a contextually valid, yet generalizable, teacher competence model that illustrates the competences as a comprehensive whole. The expert panel utilized a cyclical model building process based on creative inquiry and an expansive learning cycle. The experts identified Blömeke et al.'s (2015) teacher competence model as a fertile starting point, as the model highlights the view of teacher professional development as a continuum. We extended the model by specifying further teaching competences as observable teaching and professional practices and as situation-specific skills and by specifying a broad range of individual competencies. We sought to bring together strands of literature on teachers and teaching that have remained separate or at least not integrated as contributing to the holistic understanding of teaching. A specific feature of the multidimensional adapted process model is a more detailed depiction of teachers' noncognitive competencies that has typically been presented in the literature.

\subsection{Implications for teacher education and student selection}

Teacher knowledge-building is often emphasized in the ITE curricula, but in the framework of the MAP, as well as in the Blömeke et al. (2015) model, an argument is made that broad expertise beyond teacher knowledge forms the core of the teaching profession. From a teacher education perspective, this indicates a need to integrate the competence domains in the MAP into teacher education curricula so that at least a minimum level of competences is acquired in ITE and further developed in working life. Competences that are mostly malleable and learnable should be taught explicitly in ITE courses, practiced in teaching practicums, and/or modeled by teacher educators (Mohamed et al., 2017). For some individual competencies (e.g., personal dispositions, beliefs, and values), the goal is for students to become aware and conscious through self-reflection of the competences and their impact on teachers' work. Thus, the MAP may be useful for analyzing the content and priorities of teacher education programs and in developing ITE curricula; the model may also bring more conceptual coherence to programs that have sometimes been considered fragmented (Grossman et al., 2009). The MAP can also aid in constructing shared understandings and productive dialogue between teacher educators and supervising teachers in the schools, which has been identified as key to successful teacher education programs (Darling-Hammond, 2006). The model can also be an effective tool for professional development in the in-service phase to facilitate the continued reflection of individuals' strengths and development needs.

The MAP emphasizes a strong alliance between theory and practice and the use of knowledge to inform action. Blömeke et al.'s (2015) model indicated that theory and practice of teaching are intertwined particularly in situation-specific skills, because teachers utilize their knowledge base to interpret and reason about student thinking and other significant features of classroom interaction, to decide the next steps in instruction. In addition to knowledge-informing practice, Santagata and Yeh (2016) pointed out that teachers' perceptions, interpretations, and decision-making processes in the moment create new knowledge, thus changing the underlying competence. In line with 
this view, the MAP endorses a bidirectional relationship between teaching competences and competencies. In this this respect, the MAP differs from Blömeke et al.'s (2015) model, which has a unidirectional conceptualization of competences.

There is wide agreement that teaching careers are characterized by continuous professional development for increased proficiency and expertise at work. Thus, teacher education programs should provide students with a high-level basic or novice competence rather than aiming to prepare fully formed teachers (Brouwer \& Korthagen, 2005; McMahon et al., 2015). The MAP emphasizes teachers' propensity for professional development as it is considered one of the professional competences. Although professional development is often driven by the needs of organizations or curricular changes, at the core is a teacher's willingness to learn and incorporate new understanding into practice (Maurer, 2002). This view aligns with the models of learning that emphasize individuals' abilities and motivation to identify and address their own learning needs and seek learning opportunities to acquire knowledge and skills relevant for practice (Knowles, 1988).

A key aim for building the MAP was to stimulate discussion and facilitate a more theoretically driven deliberation of selection criteria for teacher students' entry into ITE. One of the key questions centers on which competences possess predictive power for later success in ITE and as a teacher. The MAP seeks to specify teaching competences that are relevant for daily work and practice as a teacher (e.g., quality of instruction, class management, and general and subject-specific pedagogy), which typically constitute the core content of teacher education programs. However, in the context of the present study (i.e., Finnish teacher education), candidates are not expected to possess teaching skills at entry to ITE, and simulated teaching trials are not used in the admission stage although they are included in other student selection protocols (Bowles et al., 2014; Klassen \& Kim, 2017). Thus, the MAP directs attention to individual competencies, many of which represent the candidate's potential to successfully complete teacher education or indicate general suitability for the teacher profession.

Experiences from medical and health education indicate that a robust selection system assesses candidates' cognitive and noncognitive competencies (Bore et al., 2009). Cognitive competencies assessed by academic records and standardized tests are among the best predictors of students' future academic achievement in any study program (Kuncel et al., 2004), and they predict teaching quality in working life (Klassen \& Kim, 2019). Some educational systems (e.g., Finland) also use tasks designed to capture differences between applicants' higher-order information-processing skills, such as reasoning, understanding, analyzing, and evaluating information which support successful completion of ITE. There is less evidence of the predictive value of noncognitive competencies in the selection phase, their development in ITE, and their role in success in working life. In many ITE programs, providing courses in social-emotional competence, for instance, is a low priority (Waajid et al., 2013), while other programs offer separate courses focusing on these skills (Kostiainen et al., 2018). A case can be made that candidates should possess critical competences, learning of which is not sufficiently supported in ITE, in the entry phase into the teacher education program (Casey \& Childs, 2007), suggesting the need to consider selection criteria in relation to the ITE curriculum. Thus, it is critical to note the disparity that noncognitive competencies included in the MAP, such as relational, emotional, and diversity 
competencies, and beliefs on teaching and learning, and motivation for teacher career are considered to be at the heart of teacher's work, but they typically have a minor presence in the teacher education curricula.

\section{Conclusions}

The MAP was built in a process that included dialogue, negotiation, and interpretation of teacher research to identify the teacher competences and research evidence that support them. Instead of a full-fledged systematic review, we aimed at identifying highprofile studies - reviews, meta-analyses, and large-scale international studies - to support the selection of key domains. We acknowledge that the lack of a systematic review is a limitation of this study, but we consider this work to be an important step in efforts to holistically describe key competences in the teaching profession. The competence domains selected for inclusion in the MAP represent categories backed by associated literature, and each dimension consists of subskills. In many instances, we had to limit the literacy review to the essentials rather than giving a full account. For the sake of clarity, we discussed the three main domains of the model (i.e., teaching competences, situation-specific skills, and individual competencies) separately, but we acknowledge that they are interconnected and develop reciprocally. Moreover, although research findings on Blömeke et al.'s (2015) model are accumulating in the literature (e.g., Blömeke et al., 2020), the interrelations between the competence domains as they are displayed in the MAP have not been confirmed with direct empirical evidence. There is a clear need to test the MAP empirically to draw more conclusive inferences about the competences and their interrelationships.

Aligning with the notion that attempts to produce a fully acultural model of teaching are likely to be unsuccessful, the MAP is of necessity a reflection of what is seen as skilled teaching in the Finnish educational landscape. However, although the specific competences may vary across educational systems, and some may be definable only from within the culture (emic approach), the fundamental distinctions (e.g., overt indicators of teaching competences vs. underlying mental resources conceptualized as competencies) and mechanisms (e.g., the role of situation-specific skills as a transforming mediator) likely bear a resemblance across cultures (etic approach). The same applies to teaching in different specializations or age groups. For example, content knowledge may be more relevant for teachers working in the upper secondary contexts compared to teachers in the preprimary context. These propositions should be investigated in future studies.

The MAP assumes relations between domains in the model, and future research should examine the proposed pathways in the model to specify these dynamic influences empirically. Currently, for instance, we can only speculate whether certain competences are additive (i.e., making single independent contributions to teacher effectiveness) or multiplicative (i.e., their combination brings about a level of performance not otherwise achievable). In addition, some of the underlying teacher competencies may have a direct influence on teaching practices, while some do not. The contribution of the multidimensional adapted process model of teaching is to provide a coherent framework depicting various levels of teacher competence and a 
comprehensive account of the core knowledge and skills that constitute teaching, thus bringing added value to understanding of the teaching profession.

\section{Appendix 1}

Table 2 The process of developing the MAP

\begin{tabular}{llc}
\hline Key activity & Location & Participants \\
\hline $\begin{array}{l}\text { September 2017: Expert panela meeting 1 } \\
\text { Defining objectives; Reviewing frameworks, models, and literature }\end{array}$ & JYU & 8 \\
October 2017: Steering group meetings ${ }^{\mathrm{b}-I I}$ & UTU; Remote & 14-19 \\
Reviewing the student selection criteria used in Finnish & Access &
\end{tabular}

ITE units; Choosing Blömeke et al.'s (2015) competence model as the basic framework; First draft of the MAP

November 2017: Expert panel meeting 2

Discussing cognitive and noncognitive competencies and teacher effectiveness; First proposal of the five dimensions of competencies

December 2017: Steering group meeting III

Checkpoint; Setting the schedule for the year 2018

January 2018: Expert panel meeting 3, Steering group meeting IV

Redefining competencies

February 2018: Steering group meeting V

Reviewing materials for presenting the MAP to ITE staff and stakeholders

UTU; Remote
Access
UH; Remote
$\quad 11-21$
Access
$\begin{aligned} & \text { UTU; Remote } \\ & \text { Access }\end{aligned}$

February-April 2018

Presenting the MAP in (a) staff meetings in all Finnish ITE units; (b) events including representatives of the Ministry of Education and Culture and the Trade Union of Education in Finland, and (c) project seminar; Feedback from participants

March-April 2018: Steering group meetings VI-VII

Refining the MAP based on feedback (e.g., adding relevant

UTU; Remote 20 concepts); Discussing implications for student selection and ITE

May-October 2018: Specifying the research base

JYU, UTU

Imposing a taxonomy for noncognitive competencies and personal orientations

October-December 2018: Steering group meetings VIII-IX

Introducing the MAP in various research gatherings (e.g.,

UTU; Remote

Access the Finnish Educational Research Association Conference); Finalizing the MAP

\footnotetext{
a The authors of the present study

$\mathrm{b}$ The steering group consisted of representatives from the universities of Helsinki (HY), Eastern Finland, Jyväskylä (JYU), Lapland, Oulu, Tampere, and Turku (UTU), and Åbo Akademi (29 members). Two student
}

Acknowledgements The authors would like to express their gratitude and appreciation to Kirsi HeikkinenJokilahti and the collaborators for their contribution to the MAP. 
Code availability Not applicable

Funding Open access funding provided by University of Jyväskylä (JYU). This work was supported by Academy of Finland (nr. 292466) and by a grant awarded by the Finnish Ministry of Education and Culture to implement the national government initiated Teacher Education Development Programme. The project "Student Selection to Teacher Education in Finland - Anticipatory Work for Future" was coordinated by the University of Turku and involves all universities providing teacher education unit in Finland.

Data availability Not applicable

\section{Declarations}

Conflict of interest $\mathbf{t}$ The authors declare no competing interests.

Open Access This article is licensed under a Creative Commons Attribution 4.0 International License, which permits use, sharing, adaptation, distribution and reproduction in any medium or format, as long as you give appropriate credit to the original author(s) and the source, provide a link to the Creative Commons licence, and indicate if changes were made. The images or other third party material in this article are included in the article's Creative Commons licence, unless indicated otherwise in a credit line to the material. If material is not included in the article's Creative Commons licence and your intended use is not permitted by statutory regulation or exceeds the permitted use, you will need to obtain permission directly from the copyright holder. To view a copy of this licence, visit http://creativecommons.org/licenses/by/4.0/.

\section{References}

Bardach, L., Rushby, J. V., Kim, L. E., \& Klassen, R. M. (2021). Using video-and text-based situational judgement tests for teacher selection: a quasi-experiment exploring the relations between test format, subgroup differences, and applicant reactions. European Journal of Work and Organizational Psychology, 30(2), 251-264. https://doi.org/10.1080/1359432X.2020.1736619.

Baumeister, R. F. (1999). Self-concept, self-esteem, and identity. In V. J. Derlega, B. A. Winstead, \& W. H. Jones (Eds.), Nelson-Hall series in psychology. Personality: Contemporary theory and research (p. 339375). Nelson-Hall Publishers.

Baumert, J., \& Kunter, M. (2013). The COACTIV model of teachers' professional competence. In M. Kunter, J. Baumert, W. Blum, U. Klusmann, S. Krauss, \& M. Neubrand (Eds.), Cognitive activation in the mathematics classroom and professional competence of teachers: Results from the COACTIV Project (pp. 25-48). Springer.

Baumert, J., Kunter, M., Blum, W., Brunner, M., Voss, T., Jordan, A., \& Tsai, Y. M. (2010). Teachers' mathematical knowledge, cognitive activation in the classroom, and student progress. American Educational Research Journal, 47(1), 133-180. https://doi.org/10.3102/0002831209345157.

Beauchamp, C., \& Thomas, L. (2009). Understanding teacher identity: An overview of issues in the literature and implications for teacher education. Cambridge Journal of Education, 39(2), 175-189. https://doi.org/ 10.1080/03057640902902252.

Beijaard, D., Meijer, P., \& Verloop, N. (2004). Reconsidering research on teachers' professional identity. Teaching and Teacher Education, 20(2), 107-128. https://doi.org/10.1016/j.tate.2003.07.001.

Beltman, S., Mansfield, C., \& Price, A. (2011). Thriving not just surviving: A review of research on teacher resilience. Educational Research Review, 6(3), 185-207. https://doi.org/10.1016/j.edurev.2011.09.001.

Bennet, D., \& Bennet, A. (2008). Engaging tacit knowledge in support of organizational learning. VINE, 38(1), 72-94. https://doi.org/10.1108/03055720810870905.

Bennett, M. (2009). Defining, measuring, and facilitating intercultural learning: A conceptual introduction to the intercultural education double supplement. Intercultural Education, 20, 1-13. https://doi.org/10.1080/ 14675980903370763.

Berliner, D. (2001). Learning about and learning from expert teachers. International Journal of Educational Research, 35(5), 463-482. https://doi.org/10.1016/S0883-0355(02)00004-6. 
Binkley, M., Erstad, O., Herman, J., Raizen, S., Ripley, M., Miller-Ricci, M., \& Rumble, M. (2012). Defining twenty-first century skills. In P. Griffin, B. McGaw, \& E. Care (Eds.), Assessment and teaching of 21st century skills (pp. 17-66). Springer.

Blömeke, S. (2017). Modelling teachers' professional competence as a multi-dimensional construct. In S. Guerriero (Ed.), Pedagogical knowledge and the changing nature of the teaching profession (pp. 119135). OECD Publishing.

Blömeke, S., \& Kaiser, G. (2017). Understanding the development of teachers' professional competencies as personally, situationally, and societally determined. In D. J. Clandinin \& J. Husu (Eds.), International handbook of research on teacher education (pp. 783-802). Sage.

Blömeke, S., Gustafsson, J., \& Shavelson, R. (2015). Beyond dichotomies: Competence viewed as a continuum. Zeitschrift für Psychologie, 223, 3-13. https://doi.org/10.1027/2151-2604/a000194.

Blömeke, S., Kaiser, G., König, J., \& Jentsch, A. (2020). Profiles of mathematics teachers' competence and their relation to instructional quality. ZDM, 52(2), 329-342. https://doi.org/10.1007/s11858-020-01128-y.

Booth, T., \& Ainscow, M. (2011). Index for inclusion: Developing learning and participation in schools. Centre for Studies on Inclusive Education.

Bore, M., Munro, D., \& Powis, D. (2009). A comprehensive model for the selection of medical students. Medical Teacher, 31, 1066-1072. https://doi.org/10.3109/01421590903095510.

Bowles, T., Hattie, J., Dinham, S., Scull, J., \& Clinton, J. (2014). Proposing a comprehensive model for identifying teaching candidates. The Australian Educational Researcher, 41(4), 365-380. https://doi.org/ 10.1007/s13384-014-0146-Z.

Brouwer, N., \& Korthagen, F. (2005). Can teacher education make a difference? American Educational Research Journal, 42(1), 153-224.

Bruckmaier, G., Krauss, S., Blum, W., \& Leiss, D. (2016). Measuring mathematics teachers' professional competence by using video clips (COACTIV video). ZDM Mathematics Education, 48(1-2), 111-124.

Buehl, M. M., \& Alexander, P. A. (2009). Beliefs about learning in academic domains. In K. R. Wentzel \& A. Wigfield (Eds.), Handbook of motivation at school (pp. 479-501). Routledge. https://doi.org/10.1207/ S1532690XCI2103 01.

Burgoyne, J. (1989). Creating the managerial portfolio: Building on competency approaches to management development. Management Education and Development, 20(1), 56-61. https://doi.org/10.1177/ 135050768902000109.

Casey, C., \& Childs, R. A. (2007). Teacher education program admission criteria and what beginning teachers need to know to be successful teachers. Canadian Journal of Educational Administration and Policy, 67, 1-24. Retrieved August 6, 2017, from http://www.umanitoba.ca/publications/cjeap/pdf_files/childs_ casey.pdf

Campbell, E. (2008a). Teaching ethically as a moral condition of professionalism. In L. Nucci \& D. Narváez (Eds.), The international handbook of moral and character education (pp. 601-617). Routledge.

Campbell, E. (2008b). The ethics of teaching as a moral profession. Curriculum Inquiry, 38(4), 357-385. https://doi.org/10.1111/j.1467-873X.2008.00414.x.

Casey, C., \& Childs, R. A. (2007). Teacher education program admission criteria and what beginning teachers need to know to be successful teachers. Canadian Journal of Educational Administration and Policy, 67, 1-24 Retrieved from http://www. umanitoba.ca/ publications/cjeap/pdf_files/childs_casey.pdf.

Chan, K. K. H., Xu, L., Cooper, R., Berry, A., \& van Driel, J. H. (2021). Teacher noticing in science education: Do you see what I see? Studies in Science Education, 57(1), 1-44.

Chory-Assad, R. (2002). Classroom justice: Perceptions of fairness as a predictor of student motivation, learning, and aggression. Communication Quarterly, 50(1), 58-77. https://doi.org/10.1080/ 01463370209385646.

Cochran-Smith, M., \& Lytle, S. (1999). Relationships of knowledge and practice: Teacher learning in communities. Review of Research in Education, 24(1), 249-305. https://doi.org/10.3102/ 0091732 X024001249.

Costa Jr., P., \& McCrae, R. (1992). Four ways five factors are basic. Personality and Individual differences, 13(6), 653-665. https://doi.org/10.1016/0191-8869(92)90236-I.

Cothran, D., Kulinna, P., \& Garrahy, D. (2003). “This is kind of giving a secret away...”: students' perspectives on effective class management. Teaching and Teacher Education, 19(4), 435-444. https:// doi.org/10.1016/S0742-051X(03)00027-1.

Danielson, C. (2013). The framework for teaching evaluation instrument. 2013 edition. Retrieved August 18, 2018, from http://www.loccsd.ca/ div15/wp-content/uploads/2015/09/2013-framework-for-teachingevaluation-instrument.pdf

Danielson, C. (1996). Enhancing professional practice: A framework for teaching. Association for Supervision and Curriculum Development. 
Danielson, C. (2013). The framework for teaching evaluation instrument. 2013 edition. Retrieved from http:// www.loccsd.ca/ div15/wp-content/uploads/2015/09/2013-framework-for-teaching-evaluationinstrument.pdf

Darling-Hammond, L. (2006). Powerful teacher education: Lessons from exemplary programs. Jossey-Bass.

Deardorff, D. (2006). Identification and assessment of intercultural competence as a student outcome of internationalization. Journal of Studies in International Education, 10(3), 241-266. https://doi.org/10. $1177 / 1028315306287002$.

Denham, S. (2005). Assessing social-emotional development in children from a longitudinal perspective for the National Children's Study: Social-emotional compendium of measures. George Mason University, Fairfax.

Denham, S., Blair, K., DeMulder, E., Levitas, J., Sawyer, K., \& Auerbach-Major, S., \& Queenan, P. (2003). Preschool emotional competence: Pathway to social competence? Child Development, 74(1), 238-256. https://doi.org/10.1111/1467-8624.00533.

Denham, S., Wyatt, T., Bassett, H., Echeverria, D., \& Knox, S. (2009). Assessing social-emotional development in children from a longitudinal perspective. Journal of Epidemiology \& Community Health, 63(Suppl 1), i37-i52. https://doi.org/10.1136/jech.2007.070797.

Desimone, L. M. (2009). Improving impact studies of teachers' professional development: Toward better conceptualizations and measures. Educational Researcher, 38(3), 181-199. https://doi.org/10.3102/ 0013189X08331140.

Dinham, S., \& Scott, C. (2000). Moving into the third, outer domain of teacher satisfaction. Journal of Educational Administration, 38(4), 379-396. https://doi.org/10.1108/09578230010373633.

Dobbins, K. (2009). Teacher creativity within the current education system: A case study of the perceptions of primary teachers. Education 3-13, 37(2), 95-104. https://doi.org/10.1080/03004270802012632.

Duffy, G., Miller, S., Parsons, S., \& Meloth, M. (2009). Teachers as metacognitive professionals. In D. Hacker, J. Dunlosky, \& A. Graesser (Eds.), Handbook of Metacognition in Education (pp. 240-256). Taylor \& Francis.

Dwyer, C., Hogan, M., \& Stewart, I. (2014). An integrated critical thinking framework for the 21 st century. Thinking Skills and Creativity, 12(2014), 43-52. https://doi.org/10.1016/j.tsc.2013.12.004.

Eccles, J. (2005). Subjective task values and the Eccles et al. model of achievement related choices. In A. Elliot \& C. Dweck (Eds.) Handbook of competence and motivation (pp. 105-121). Guilford.

Engeström, Y., \& Sannino, A. (2010). Studies of expansive learning: Foundations, findings and future challenges. Educational Research Review, 5(1), 1-24. https://doi.org/10.1016/j.edurev.2009.12.002.

Ertmer, P. A., \& Newby, T. J. (2013). Behaviorism, cognitivism, constructivism: Comparing critical features from an instructional design perspective. Performance Improvement Quarterly, 26(2), 43-71. https://doi. org/10.1111/j.1937-8327.1993.tb00605.x.

Eteläpelto, A., Vähäsantanen, K., Hökkä, P., \& Paloniemi, S. (2013). What is agency? Conceptualizing professional agency at work. Educational Research Review, 10(2013), 45-65. https://doi.org/10.1016/j. edurev.2013.05.001.

García-Arroyo, J. A., Osca Segovia, A., \& Peiró, J. M. (2019). Meta-analytical review of teacher burnout across 36 societies: The role of national learning assessments and gender egalitarianism. Psychology \& Health, 34(6), 733-753. https://doi.org/10.1080/08870446.2019.1568013.

García-Carmona, M., Marín, M. D., \& Aguayo, R. (2019). Burnout syndrome in secondary school teachers: A systematic review and meta-analysis. Social Psychology of Education, 22(1), 189-208. https://doi.org/10. 1007/s11218-018-9471-9.

Gess-Newsome, J. (1999). Pedagogical content knowledge: An introduction and orientation. In J. GessNewsome \& N. Lederman (Eds.), Examining pedagogical content knowledge: The construct and its implications for science education (pp. 3-17). Kluwer.

Gess-Newsome, J., Taylor, J. A., Carlson, J., Gardner, A. L., Wilson, C. D., \& Stuhlsatz, M. A. M. (2017). Teacher pedagogical content knowledge, practice, and student achievement. International Journal of Science Education, 41(7), 944-963. https://doi.org/10.1080/09500693.2016.1265158.

Goe, L., Bell, C., \& Little, O. (2008). Approaches to evaluating teacher effectiveness: A research synthesis. National Comprehensive Center for Teacher Quality Retrieved from https://eric.ed.gov/?id=ED521228.

Goh, S., \& Fraser, B. (1998). Teacher interpersonal behaviour, classroom environment and student outcomes in primary mathematics in Singapore. Learning Environments Research, 1, 199-229. https://doi.org/10. 1023/A:1009910017400.

Gottfredson, L. S. (1997). Intelligence and social policy. Intelligence, 24(1), 1-12.

Graber, K. (1996). Influencing student beliefs: The design of a high impact teacher education program. Teaching and Teacher Education, 12(5), 451-466. https://doi.org/10.1016/0742-051X(95)00059-S. 
Grant, M. J., \& Booth, A. (2009). A typology of reviews: an analysis of 14 review types and associated methodologies. Health Information \& Libraries Journal, 26(2), 91-108. https://doi.org/10.1111/j.14711842.2009.00848.x.

Grossman, P., \& McDonald, M. (2008). Back to the future: Directions for research in teaching and teacher education. American Educational Research Journal, 45(1), 184-205. https://doi.org/10.3102/ 0002831207312906.

Grossman, P., Hammerness, K., \& McDonald, M. (2009). Redefining teaching, re-imagining teacher education. Teachers and Teaching: Theory and practice, 15(2), 273-289. https://doi.org/10.1080/ 13540600902875340.

Gu, Q., \& Day, C. (2007). Teachers' resilience: A necessary condition for effectiveness. Teaching and Teacher Education, 23(8), 1302-1316. https://doi.org/10.1016/j.tate.2006.06.006.

Guerriero, S. (Ed.). (2017). Pedagogical knowledge and the changing nature of the teaching profession. OECD Publishing, Paris. Retrieved October 4, 2018, https://doi.org/10.1787/9789264270695-6-en.

Guerriero, S., \& Révai, N. (2017). Knowledge-based teaching and the evolution of a profession. In S. Guerriero (Ed.), Pedagogical knowledge and the changing nature of the teaching profession. OECD Publishing.

Guo, Y., Connor, C. M., Yang, Y., Roehrig, A. D., \& Morrison, F. J. (2012). The effects of teacher qualification, teacher self-efficacy, and classroom practices on fifth graders' literacy outcomes. The Elementary School Journal, 113(1), 3-24. https://doi.org/10.1086/665816.

Hakanen, J., Bakker, A., \& Schaufeli, W. B. (2006). Burnout and work engagement among teachers. Journal of School Psychology, 43(6), 495-513. https://doi.org/10.1016/j.jsp.2005.11.001.

Häkkinen, P., Järvelä, S., Mäkitalo-Siegl, K., Ahonen, A., Näykki, P., \& Valtonen, T. (2017). Preparing teacher-students for twenty-first-century learning practices (PREP 21): A framework for enhancing collaborative problem-solving and strategic learning skills. Teachers and Teaching, 23(1), 25-41. https://doi.org/10.1080/13540602.2016.1203772.

Hamre, B., \& Pianta, R. (2005). Can instructional and emotional support in the first-grade classroom make a difference for children at risk of school failure? Child Development, 76(5), 949-967. https://doi.org/10. 1111/j.1467-8624.2005.00889.x.

Hamre, B., Pianta, R., Downer, J., DeCoster, J., Mashburn, A., Jones, S., ... \& Brackett, M. (2013). Teaching through interactions: Testing a developmental framework of teacher effectiveness in over 4,000 classrooms. Elementary School Journal, 113(4), 461-487. https://doi.org/10.1086/669616

Hanushek, E. A., Piopiunik, M., \& Wiederhold, S. (2019). The value of smarter teachers international evidence on teacher cognitive skills and student performance. Journal of Human Resources, 54(4), 857-899. https://doi.org/10.3368/jhr.54.4.0317.8619R1.

Hargreaves, A. (1998). The emotional practice of teaching. Teaching and Teacher Education, 14(8), 835-854. https://doi.org/10.1016/S0742-051X(98)00025-0.

Harris, A. (2009). Distributed leadership: What we know? In A. Harris (Ed.), Distributed Leadership: Different Perspectives (pp. 11-21). Springer. https://doi.org/10.1007/978-1-4020-9737-9_2.

Hattie, J. (2009). Visible learning: A synthesis of 800+ meta-analyses on achievement. Routledge.

Heckman, J., \& Kautz, T. (2012). Hard evidence on soft skills. Labour Economics, 19(4), 451-464. https:// doi.org/10.1016/j.labeco.2012.05.014.

Herman, K. C., Hickmon-Rosa, J. E., \& Reinke, W. M. (2018). Empirically derived profiles of teacher stress, burnout, self-efficacy, and coping and associated student outcomes. Journal of Positive Behavior Interventions, 20(2), 90-100. https://doi.org/10.1177/1098300717732066.

Hill, H., Rowan, B., \& Ball, D. (2005). Effects of teachers' mathematical knowledge for teaching on student achievement. American Educational Research Journal, 42(2), 371-406. https://doi.org/10.3102/ 00028312042002371.

Hobson, A. J., Ashby, P., McIntyre, J., \& Malderez, A. (2010). International approaches to teacher selection and recruitment. OECD Education Working Papers, No. 47, OECD Publishing, https://doi.org/10.1787/ $5 \mathrm{kmbphhh6qmx-en}$

Husu, J., \& Tirri, K. (2001). Teachers' ethical choices in sociomoral settings. Journal of Moral Education, 30(4), 361-375. https://doi.org/10.1080/03057240120094850.

Jennings, P., \& Greenberg, M. (2009). The prosocial classroom: Teacher social and emotional competence in relation to student and classroom outcomes. Review of Educational Research, 79(1), 491-525. https://doi. org/10.3102/0034654308325693.

Klassen, R. M., Durksen, T. L., Al Hashmi, W., Kim, L. E., Longden, K., Metsäpelto, R.-L., Poikkeus, A.-M., \& Györi, J. (2018). National context and teacher characteristics: Exploring the critical non-cognitive attributes of novice teachers in four countries. Teaching and Teacher Education, 72, 64-74. https://doi. org/10.1016/j.tate.2018.03.001 
Kaiser, G., Busse, A., Hoth, J., König, J., \& Blömeke, S. (2015). About the complexities of video-based assessments: Theoretical and methodological approaches to overcoming shortcomings of research on teachers' competence. International Journal of Science and Mathematics Education, 13, 369-387. https:// doi.org/10.1007/s10763-015-9616-7.

Kallio, H., Kallio, M., Virta, K., Iiskala, T., \& Hotulainen, R. (2020). Teachers' support for learners' metacognitive awareness. Scandinavian Journal of Educational Research, 1-17. https://doi.org/10. 1080/00313831.2020.1755358

Karhu, A., Närhi, V., \& Savolainen, H. (2019). Check in-check out intervention for supporting pupils' behaviour: Effectiveness and feasibility in Finnish schools. European Journal of Special Needs Education, 34(1), 136-146. https://doi.org/10.1080/08856257.2018.1452144.

Kasalak, G., \& Dagyar, M. (2020). The relationship between teacher self-efficacy and teacher job satisfaction: A meta-analysis of the teaching and learning international survey (TALIS). Educational Sciences: Theory and Practice, 20(3), 16-33.

Keller, M., Frenzel, A., Goetz, T., Pekrun, R., \& Hensley, L. (2014). Exploring teacher emotions: A literature review and an experience sampling study. In P. Richardson, S. Karabenick, \& H. Watt (Eds.), Teacher motivation: Theory and practice (pp. 69-82). Routledge.

Kersting, N. (2008). Using video clips of mathematics classroom instruction as item prompts to measure teachers' knowledge of teaching mathematics. Educational and Psychological Measurement, 68(5), 845861. https://doi.org/10.1177/0013164407313369.

Kersting, N., Givvin, K., Thompson, B., Santagata, R., \& Stigler, J. (2012). Measuring usable knowledge: Teachers' analyses of mathematics classroom videos predict teaching quality and student learning. American Educational Research Journal, 49(3), 568-589. https://doi.org/10.3102/0002831212437853.

Kilinç, A. (2014). Examining the relationship between teacher leadership and school climate. Educational Sciences: Theory \& Practice, 14(5), 1729-1742. https://doi.org/10.12738/estp.2014.5.2159.

Kim, L. E., Dar-Nimrod, I., \& MacCann, C. (2018). Teacher personality and teacher effectiveness in secondary school: Personality predicts teacher support and student self-efficacy but not academic achievement. Journal of Educational Psychology, 110(3), 309-323. https://doi.org/10.1037/edu0000217.

Kim, L. E., Jörg, V., \& Klassen, R. (2019). A meta-analysis of the effects of teacher personality on teacher effectiveness and burnout. Educational Psychology Review, 31, 1-33. https://doi.org/10.1007/s10648018-9458-2.

Klassen, R. M., \& Kim, L. E. (2017). Assessing critical attributes of prospective teachers: Implications for selection into initial teacher education programs. In D. W. Putwain \& K. Smart (Eds.), British Journal of Educational Psychology Monograph Series II: Psychological Aspects of Education (pp. 5-22). Wiley.

Klassen, R. M., \& Kim, L. (2019). Selecting teachers and prospective teachers: A meta-analysis. Educational Research Review, 26(2019), 32-51. https://doi.org/10.1016/j.edurev.2018.12.003.

Klassen, R., \& Tze, V. (2014). Teachers' self-efficacy, personality, and teaching effectiveness: A metaanalysis. Educational Research Review, 12(2014), 59-76. https://doi.org/10.1016/j.edurev.2014.06.001.

Klusmann, U., Kunter, M., Trautwein, U., Lüdtke, O., \& Baumert, J. (2008). Teachers' occupational wellbeing and quality of instruction: The important role of self-regulatory patterns. Journal of Educational Psychology, 100(3), 702-715. https://doi.org/10.1037/0022-0663.100.3.702.

Knowles, M. (1988). The adult learner: A neglected species. Gulf.

Koeppen, K., Hartig, J., Klieme, E., \& Leutner, D. (2008). Current issues in competence modeling and assessment. Zeitschrift für Psychologie, 216(2), 61-73. https://doi.org/10.1027/0044-3409.216.2.61.

Kokkinos, C. (2007). Job stressors, personality and burnout in primary school teachers. British Journal of Educational Psychology, 77(1), 229-243. https://doi.org/10.1348/000709905X90344.

König, J., \& Kramer, C. (2016). Teacher professional knowledge and classroom management: On the relation of general pedagogical knowledge (GPK) and classroom management expertise (CME). ZDM, 48, 139151. https://doi.org/10.1007/s11858-015-0705-4.

König, J., Blömeke, S., Klein, P., Suhl, U., Busse, A., \& Kaiser, G. (2014). Is teachers' general pedagogical knowledge a premise for noticing and interpreting classroom situations? A video-based assessment approach. Teaching and Teacher Education, 38(2014), 76-88. https://doi.org/10.1016/j.tate.2013.11.004.

Korthagen, F. A. (2004). In search of the essence of a good teacher: Towards a more holistic approach in teacher education. Teaching and Teacher Education, 20(1), 77-97. https://doi.org/10.1016/j.tate.2003.10. 002 .

Koster, B., \& Dengerink, J. (2008). Professional standards for teacher educators: how to deal with complexity, ownership and function. Experiences from the Netherlands. European Journal of Teacher Education, 31(2), 135-149. https://doi.org/10.1080/02619760802000115. 
Kostiainen, E., Ukskoski, T., Ruohotie-Lyhty, M., Kauppinen, M., Kainulainen, J., \& Mäkinen, T. (2018). Meaningful learning in teacher education. Teaching and Teacher Education, 71, 66-77. https://doi.org/ 10.1016/j.tate.2017.12.009.

Krathwohl, D. (2002). A revision of Bloom's taxonomy: An overview. Theory into Practice, 41(4), 212-218. https://doi.org/10.1207/s15430421tip4104_2.

Kuncel, N. R., Hezlett, S. A., \& Ones, D. S. (2004). Academic performance, career potential, creativity, and job performance: Can one construct predict them all? Journal of Personality and Social Psychology, 86(1), 148-161. https://doi.org/10.1037/0022-3514.86.1.148.

Kyriacou, C. (2001). Teacher stress: Directions for future research. Educational Review, 53(1), 27-35. https:// doi.org/10.1080/00131910120033628.

Lande, E., \& Mesa, V. (2016). Instructional decision making and agency of community college mathematics faculty. ZDM, 48, 199-212. https://doi.org/10.1007/s11858-015-0736-x.

Le Roux, J. (2002). Effective educators are culturally competent communicators. Intercultural Education, 13(1), 37-48. https://doi.org/10.1080/14675980120112922.

Lerkkanen, M.-K., Kiuru, N., Pakarinen, E., Poikkeus, A.-M., Rasku-Puttonen, H., Siekkinen, M., \& Nurmi, J. E. (2016). Child-centered versus teacher-directed teaching practices: Associations with the development of academic skills in the first grade at school. Early Childhood Research Quarterly, 36(2016), 145-156. https://doi.org/10.1016/j.ecresq.2015.12.023.

Metsäpelto, R. L., Utriainen, J., Poikkeus, A.-M., Muotka, J., Tolvanen, A., \& Warinowski, A. (in press). Multiple mini interview in student selection for initial teacher education admissions

Mishra, P., \& Koehler, M. J. (2006). Technological pedagogical content knowledge: A framework for teacher knowledge. Teachers College Record, 108(6), 1017-1054. Retrieved February 14, 2020, from https:// www.learntechlib.org/p/99246/

Madigan, D. J., \& Kim, L. E. (2021). Does teacher burnout affect students? A systematic review of its association with academic achievement and student-reported outcomes. International Journal of Educational Research, 105, 101714. https://doi.org/10.1016/j.ijer.2020.101714.

Madni, A., Baker, E., Chow, K., Delacruz, G., \& Griffin, N. (2015). Assessment of teachers from a social psychological perspective. Review of Research in Education, 39(1), 54-86. https://doi.org/10.3102/ 0091732 X14558203.

Mansfield, C. F., Beltman, S., Broadley, T., \& Weatherby-Fell, N. (2016). Building resilience in teacher education: An evidenced informed framework. Teaching and Teacher Education, 54, 77-87. https://doi. org/10.1016/j.tate.2015.11.016.

Maslach, C., Schaufeli, W., \& Leiter, M. (2001). Job burnout. Annual Review of Psychology, 52(2001), 397422. https://doi.org/10.1146/annurev.psych.52.1.397.

Maurer, T. (2002). Employee learning and development orientation: Toward an integrative model of involvement in continuous learning. Human Resource Review, 1(1), 9-44. https://doi.org/10.1177/ 1534484302011002.

McAdams, D., \& Pals, J. (2006). A new big five: Fundamental principles for an integrative science of personality. American Psychologist, 61(3), 204-217. https://doi.org/10.1037/0003-066X.61.3.204.

McMahon, M., Forde, C., \& Dickson, B. (2015). Reshaping teacher education through the professional continuum. Educational Review, 67(2), 158-178. https://doi.org/10.1080/00131911.2013.846298.

Mercer, N. (1996). The quality of talk in children's collaborative activity in the classroom. Learning and Instruction, 6(4), 359-377. https://doi.org/10.1016/S0959-4752(96)00021-7.

Miller, K. (2011). Situation awareness in teaching: What educators can learn from video-based research in other fields? In M. Sherin, V. Jacobs, \& R. Philipp (Eds.), Mathematics teacher noticing: Seeing through teachers' eyes (pp. 51-65). Routledge.

Mishra, P., \& Koehler, M. J. (2006). Technological pedagogical content knowledge: A framework for teacher knowledge. Teachers College Record, 108(6), 1017-1054 Retrieved from https://www.learntechlib.org/p/ 99246/.

Mohamed, Z., Valcke, M., \& De Wever, B. (2017). Are they ready to teach? Student teachers' readiness for the job with reference to teacher competence frameworks. Journal of Education for Teaching, 43(2), 151170. https://doi.org/10.1080/02607476.2016.1257509.

Montuori, A. (2005). Literature review as creative inquiry: Reframing scholarship as a creative process. Journal of Transformative Education, 3(4), 374-393. https://doi.org/10.1177/1541344605279381.

Morris, D., Usher, E., \& Chen, J. (2017). Reconceptualizing the sources of teaching self-efficacy: A critical review of emerging literature. Educational Psychology Review, 29(4), 795-833. https://doi.org/10.1007/ s10648-016-9378-y. 
Newman, R. (2000). Social influences on the development of children's adaptive help seeking: The role of parents, teachers, and peers. Developmental Review, 20(3), 350-404. https://doi.org/10.1006/drev.1999. 0502 .

Nurmi, J.-E., \& Kiuru, N. (2015). Students' evocative impact on teacher instruction and teacher-child relationships: Theoretical background and an overview of previous research. International Journal of Behavioral Development, 39(5), 445-457. https://doi.org/10.1177/0165025415592514.

Paine, L., Blömeke, S., \& Aydarova, O. (2016). Teachers and teaching in the context of globalization. In D. H. Gitomer \& C. A. Bell (Eds.), Handbook of research on teaching (pp. 717-786). American Educational Research Association. https://doi.org/10.3102/978-0-935302-48-6_11.

Perry, K. E., Donohue, K. M., \& Weinstein, R. S. (2007). Teaching practices and the promotion of achievement and adjustment in first grade. Journal of School Psychology, 45(3), 269-292. https://doi. org/10.1016/j.jsp.2007.02.005.

Pianta, R., Hamre, B., \& Allen, J. (2012). Teacher-student relationships and engagement: Conceptualizing, measuring, and improving the capacity of classroom interactions. In S. Christenson, A. Reschly, \& C. Wylie (Eds.), Handbook of research on student engagement (pp. 365-386). Springer. https://doi.org/10. 1007/978-1-4614-2018-7 17.

Pietarinen, J., Pyhältö, K., Soini, T., \& Salmela-Aro, K. (2013). Reducing teacher burnout: A socio-contextual approach. Teaching and Teacher Education, 35(2015), 62-72. https://doi.org/10.1016/j.tate.2013.05.003.

Praetorius, A. K., Klieme, E., Herbert, B., \& Pinger, P. (2018). Generic dimensions of teaching quality: the German framework of three basic dimensions. ZDM, 50(3), 407-426. https://doi.org/10.1007/s11858018-0918-4.

Richardson, V. (1996). The role of attitudes and beliefs in learning to teach. In J. Sikula, T. Buttery, \& E. Guyton (Eds.), Handbook of research on teacher education (pp. 102-119). Simon \& Schuster Macmillan.

Richardson, P., \& Watt, H. (2014). Why people choose teaching as a career: An expectancy-value approach to understanding teacher motivation. In P. Richardson, S. Karabenick, \& H. Watt (Eds.), Teacher motivation: Theory and practice (pp. 25-41). Routledge.

Richardson, P., Karabenick, S., \& Watt, H. (Eds.). (2014). Teacher motivation: Theory and practice. Routledge.

Roloff, J., Klusmann, U., Lüdtke, O., \& Trautwein, U. (2020). The predictive validity of teachers' personality, cognitive and academic abilities at the end of high school on instructional quality in Germany: A longitudinal study. AERA Open, 6(1), 1-17. https://doi.org/10.1177/2332858419897884.

Rosiek, J., \& Beghetto, R. (2009). Emotional scaffolding: The emotional and imaginative dimensions of teaching and learning. In P. Schutz \& M. Zembylas (Eds.), Advances in teacher emotion research (pp. 175-194). Springer. https://doi.org/10.1007/978-1-4419-0564-2_9.

Sahlberg, P. (2010). The secret to Finland's success: Educating teachers. Stanford Center for Opportunity Policy in Education, 2, 1-8. Retrieved April 24, 2019, from https:/www.edpolicy.stanford.edu/sites/ default/files/publications/secret-finlands-success-educatingteachers.pdf

Sadler, P. M., Sonnert, G., Coyle, H. P., Cook-Smith, N., \& Miller, J. L. (2013). The influence of teachers' knowledge on student learning in middle school physical science classrooms. American Educational Research Journal, 50(5), 1020-1049. https://doi.org/10.1080/09500693.2016.1265158.

Sahlberg, P. (2010). The secret to Finland's success: Educating teachers. Stanford Center for Opportunity Policy in Education, 2, 1-8 Retrieved from http://edpolicy.stanford.edu/sites/default/files/publications/ secret-finland's-success-educating-teachers.pdf.

Santagata, R., \& Yeh, C. (2016). The role of perception, interpretation, and decision making in the development of beginning teachers' competence. ZDM, 48, 153-165. https://doi.org/10.1007/s11858015-0737-9.

Schaufeli, W., Salanova, M., González-Romá, V., \& Bakker, A. (2002). The measurement of engagement and burnout: A two sample confirmatory factor analytic approach. Journal of Happiness studies, 3, 71-92. https://doi.org/10.1023/A:1015630930326.

Scheerens, J., \& Blömeke, S. (2016). Integrating teacher education effectiveness research into educational effectiveness models. Educational Research Review, 18, 70-87. https://doi.org/10.1016/j.edurev.2016.03. 002 .

Schleicher, A. (2011). Lessons from the world on effective teaching and learning environments. Journal of Teacher Education, 62(2), 202-221. https://doi.org/10.1177/0022487110386966.

Schön, D. A. (1995). Knowing-in-action: The new scholarship requires a new epistemology. Change, 27(6), 27-34.

Seidel, T., \& Shavelson, R. (2007). Teaching effectiveness research in the past decade: The role of theory and research design in disentangling meta-analysis results. Review of Educational Research, 77(4), 454-499. https://doi.org/10.3102/0034654307310317. 
Seidel, T., \& Stürmer, K. (2014). Modeling and measuring the structure of professional vision in preservice teachers. American Educational Research Journal, 51(4), 739-771. https://doi.org/10.3102/ 0002831214531321.

Shavelson, R., \& Stern, P. (1981). Research on teachers' pedagogical thoughts, judgments, decisions, and behavior. Review of Educational Research, 51(4), 455-498. https://doi.org/10.2307/1170362.

Sherin, M., Jacobs, V., \& Philipp, R. (Eds.). (2011). Mathematics teacher noticing: Seeing through teachers' eyes. Routledge.

Shulman, L. (1987). Knowledge and teaching: Foundations of the new reform. Harvard Educational Review, 57(1), 1-23. https://doi.org/10.17763/haer.57.1.j463w79r56455411.

Spratt, J., \& Florian, L. (2015). Inclusive pedagogy: From learning to action. Supporting each individual in the context of "everybody". Teaching and Teacher Education, 49(2015), 89-96. https://doi.org/10.1016/j. tate.2015.03.006.

Stahnke, R., Schueler, S., \& Roesken-Winter, B. (2016). Teachers' perception, interpretation, and decisionmaking: a systematic review of empirical mathematics education research. ZDM, 48(1), 1-27. https://doi. org/10.1007/s11858-016-0775-y.

Steffensky, M., Gold, B., Holdynski, M., \& Möller, K. (2015). Professional vision of classroom management and learning support in science classrooms-Does professional vision differ across general and contentspecific classroom interactions? International Journal of Science and Mathematics Education, 13(2), 351-368. https://doi.org/10.1007/s10763-014-9607-0.

Sternberg, R., \& Horvath, J. (1995). A prototype view of expert teaching. Educational Researcher, $24,9-17$. https://doi.org/10.2307/1176079.

Stoll, L., Bolam, R., McMahon, A., Wallace, M., \& Thomas, S. (2006). Professional learning communities: A review of the literature. Journal of Educational Change, 7, 221-258. https://doi.org/10.1007/s10833-0060001-8.

Stoof, A., Martens, R., Van Merrienboer, J., \& Bastiaens, T. (2002). The boundary approach of competence: A constructivist aid for understanding and using the concept of competence. Human Resource Development Review, 1(3), 345-365. https://doi.org/10.1177/1534484302013005.

Sutton, R., \& Wheatley, K. (2003). Teachers' emotions and teaching: A review of the literature and directions for future research. Educational Psychology Review, 15(4), 327-358. https://doi.org/10.1023/A: 1026131715856.

Titsworth, S., Mazer, J., Goodboy, A., Bolkan, S., \& Myers, S. (2015). Two meta-analyses exploring the relationship between teacher clarity and student learning. Communication Education, 64(4), 385-418. https://doi.org/10.1080/03634523.2015.1041998.

Toom, A., Kynäslahti, H., Krokfors, L., Jyrhämä, R., Byman, R., Stenberg, K., Maaranen, K., \& Kansanen, P. (2010). Experiences of a research-based approach to teacher education: Suggestions for future policies. European Journal of Education, 45(2), 331-344. https://doi.org/10.1111/j.1465-3435.2010.01432.x.

Tschannen-Moran, M., \& Hoy, A. (2001). Teacher efficacy: Capturing an elusive construct. Teaching and Teacher Education, 17(7), 783-805. https://doi.org/10.1016/S0742-051X(01)00036-1.

Tschannen-Moran, M., Hoy, A., \& Hoy, W. (1998). Teacher efficacy: Its meaning and measure. Review of Educational Research, 68(2), 202-248. https://doi.org/10.2307/1170754.

Tynjälä, P., Slotte, V., Nieminen, J., Lonka, K., \& Olkinuora, E. (2006). From university to working life: Graduates' workplace skills in practice. In P. Tynjälä, J. Välimaa, \& G. Boulton-Lewis (Eds.), Higher education and working life: Collaborations, confrontations and challenges (pp. 73-88). Elsevier.

Tynjälä, P., Virtanen, A., Klemola, U., Kostiainen, E., \& Rasku-Puttonen, H. (2016). Developing social competence and other generic skills in teacher education: Applying the model of integrative pedagogy. European Journal of Teacher Education, 39(3), 368-387. https://doi.org/10.1080/02619768.2016.

Van Es, E., \& Sherin, M. (2002). Learning to notice: Scaffolding new teachers' interpretations of classroom interactions. Journal of Technology and Teacher Education, 10(4), 571-596. Retrieved July 30, 2018, from https://www.learntechlib.org/primary/p/9171/

Valtonen, T., Hoang, N., Sointu, E., Näykki, P., Virtanen, A., Pöysä-Tarhonen, J., Häkkinen, P., Järvelä, S., Mäkitalo, K., \& Kukkonen, J. (2021). How pre-service teachers perceive their 21 st-century skills and dispositions: A longitudinal perspective. Computers in Human Behavior, 116, 106643. https://doi.org/10. 1016/j.chb.2020.106643.

Van den Bogert, N., van Bruggen, J., Kostons, D., \& Jochems, W. (2014). First steps into understanding teachers' visual perception of classroom events. Teaching and Teacher Education, 37(2014), 208-216. https://doi.org/10.1016/j.tate.2013.09.001.

Van Driel, J., Verloop, N., \& De Vos, W. (1998). Developing science teachers' pedagogical content knowledge. Journal of Research in Science Teaching, 35(6), 673-695. https://doi.org/10.1002/(SICI) 1098-2736(199808)35:6<673::AID-TEA5>3.0.CO;2-J. 
Van Es, E. (2011). A framework for learning to notice student thinking. In M. Sherin, V. Jacobs, \& R. Philipp (Eds.), Mathematics teacher noticing: Seeing through teachers' eyes (pp. 164-181). Routledge.

Van Es, E., \& Sherin, M. (2002). Learning to notice: Scaffolding new teachers' interpretations of classroom interactions. Journal of Technology and Teacher Education, 10(4), 571-596 Retrieved from https://www. learntechlib.org/primary/p/9171/.

Voss, T., Kunter, M., \& Baumert, J. (2011). Assessing teacher candidates' general pedagogical/psychological knowledge: Test construction and validation. Journal of Educational Psychology, 103(4), 952-969. https://doi.org/10.1037/a0025125.

Waajid, B., Garner, P. W., \& Owen, J. E. (2013). Infusing social emotional learning into the teacher education curriculum. International Journal of Emotional Education, 5(2), 31-48.

Ward, P., Kim, I., Ko, B., \& Li, W. (2015). Effects of improving teachers' content knowledge on teaching and student learning in physical education. Research Quarterly for Exercise and Sport, 86(2), 130-139. https://doi.org/10.1080/02701367.2014.987908.

Watt, H., Richardson, P., Klusmann, U., Kunter, M., Beyer, B., Trautwein, U., \& Baumert, J. (2012). Motivations for choosing teaching as a career: An international comparison using the FIT-Choice scale. Teaching and Teacher Education, 28(6), 791-805. https://doi.org/10.1016/j.tate.2012.03.003.

Weinert, F. (2001). Concept of competence: A conceptual clarification. In D. S. Rychen \& L. H. Salganik (Eds.), Defining and selecting key competencies (pp. 5-65). Hogrefe \& Huber Publishers.

Winne, P. H. (2001). Self-regulated learning viewed from models of information processing. In B. J. Zimmerman \& D. H. Schunk (Eds.), Self-regulated learning and academic achievement: Theoretical perspectives (pp. 153-189). Lawrence Erlbaum Associates Publishers.

Wolff, C. E., Jarodzka, H., \& Boshuizen, H. P. (2017). See and tell: Differences between expert and novice teachers' interpretations of problematic classroom management events. Teaching and Teacher Education, 66, 295-308. https://doi.org/10.1016/j.tate.2017.04.015.

Zee, M., \& Kooman, H. (2016). Teacher self-efficacy and its effects on classroom processes, student academic adjustments, and teacher well-being: A synthesis of 40 years of research. Review of Educational Research, 86(4), 981-1015. https://doi.org/10.3102/0034654315626801.

Publisher's note Springer Nature remains neutral with regard to jurisdictional claims in published maps and institutional affiliations.

\section{Affiliations}

\section{Riitta-Leena Metsäpelto ${ }^{1} \cdot$ Anna-Maija Poikkeus $^{1} \cdot$ Mirva Heikkilä $^{2}$ • Jukka Husu $^{2}$ - Anu Laine ${ }^{3}$ - Kristiina Lappalainen ${ }^{4}$ - Marko Lähteenmäki ${ }^{2}$ - Mirjamaija Mikkilä-Erdmann ${ }^{2}$ - Anu Warinowski ${ }^{5}$ - Tuike liskala ${ }^{2}$ - Sanna Hangelin ${ }^{2}$ - Sari Harmoinen $^{6}$ • Anni Holmström ${ }^{2}$ • Outi Kyrö-Ämmälä ${ }^{7}$ • Sami Lehesvuori ${ }^{1}$ • Ville Mankki $^{8} \cdot$ Pirjo Suvilehto $^{6}$}

1 Department of Teacher Education, University of Jyväskylä, Jyväskylä, Finland

2 Department of Teacher Education, University of Turku, Turku, Finland

3 Faculty of Educational Sciences, University of Helsinki, Helsinki, Finland

4 University of Eastern-Finland, Joensuu, Finland

5 Faculty of Education, University of Turku, Turku, Finland

6 University of Oulu, Oulu, Finland

7 University of Lapland, Rovaniemi, Finland

8 Faculty of Education and Culture, Tampere University, Tampere, Finland 